\title{
Facies
}

\section{Genesis of Late Triassic peritidal dolomites in the Transdanubian Range, Hungary --Manuscript Draft--}

Manuscript Number:

Full Title:

Article Type:

Keywords:

Corresponding Author:

FACI-D-14-00081R2

Genesis of Late Triassic peritidal dolomites in the Transdanubian Range, Hungary

Original Article

Dolomite genesis, carbonate platform, depositional cycles, diagenesis, stable isotopes, Upper Triassic, Transdanubian Range, Hungary

Janos Haas

HUNGARY

\section{Corresponding Author Secondary}

Information:

Corresponding Author's Institution:

Corresponding Author's Secondary Institution:

First Author:

Janos Haas

First Author Secondary Information:

Order of Authors:

\author{
Janos Haas \\ Georgina Lukoczki \\ Tamás Budai, DSc \\ Attila Demény, DSc
}

Order of Authors Secondary Information:

Abstract:

In the Late Triassic, a 2-3 km thick platform carbonate succession formed along the passive margin of the Tethys Ocean. Certain parts of the succession were affected by pervasive dolomitization whereas other parts are only partially dolomitized or nondolomitized. In the Transdanubian Range, Hungary, the Upper Triassic platform carbonates are extensively distributed and numerous data are available for the space and time relations of the dolomitized and non-dolomitized units. This geological setting provides a unique opportunity for the study of palaeogeographical and diagenetic controls of dolomitization of the whole platform complex. This paper present the characteristic features of the dolomite-types of the dolomite-bearing formations and lithofacies-types, with a view to interpret the dolomite-forming processes and to determine the main controlling factors of the dolomite genesis. Petrographic features and stable isotope characteristics of the studied successions suggest the predominance of penecontemporaneous and early diagenetic dolomite genesis. Study of the transitional interval between the pervasively dolomitized and the non-dolomitized sequences revealed the general presence of microcrystalline dolomite in the peritidal microbial deposits and the characteristics of partial dolomitization both in the peritidal and subtidal facies. In the peritidal facies microbially-induced $\mathrm{Ca}-\mathrm{Mg}$ carbonate precipitation is inferred, which was probably complemented by penecontemporaneous mimetic dolomitization of precursor carbonates due to evaporative pumping or seepage influx. Dolomitization of the subtidal facies took place via reflux of slightly evaporated sea-water. Dolomitization of the previously deposited carbonate mud commenced during subsequent subaerial exposure but the process of early diagenetic dolomitization may have continued during later exposure events. Recurring subaerial exposure is one of the controlling factors, determining the areal extent of the early dolomitization of the platform carbonates. However, the climatic conditions were also crucial. Although the sea-level controlled, unconformity-bound cyclic facies pattern did not change significantly in the internal platform belt during the nearly 20 My long timerange, a drier climate favoured dolomite formation while increasing humidity led to a gradual decreasing intensity of early dolomitization. 
Response to Reviewers:
Our responses to the notes and suggestions are given below.

Lines 487-491 - Accepting the note of the editor-in-chief we deleted the sentence; this unexplained statement cannot be considered as a general inference of the isotope studies.

Lines 523-527 and 594-596 - If only the pervasively dolomitized formations of the Upper Triassic platform carbonates (Gémhegy Dolomite Fm, Fődolomit Fm) are considered, application of Ginsburg's model is a realistic option and there is no unambiguous constraints for the orbital forcing; although truncation surfaces, which are locally covered by dolocretes, may indicate relatively long-term subaerial exposure. However, we emphasized the gradual transition between the pervasively dolomitized and the practically non-dolomitized segments of the platform succession and the similarities in the characteristics of the cycles. In the case of the non-dolomitized Dachstein Limestone, which formed under sub-humid to humid climate, the subaerial exposure led to meteoric dissolution and cementation. Consolidation of the previously deposited carbonate sediment was followed by erosion, karstification, accumulation of wind-blown dust and pedogenesis; i.e. establishment of continental conditions for a longer time. These features suggest eustatic control, which may justify the extrapolation of the allocyclic model for the entire platform evolution. However, coeval effects of the sea-level changes and the autocyclic processes cannot be excluded. Taking into account the above summarized argumentation we modified the composition of the text (Lines 510-516 in the modified version).

Lines 659-661 - No, we have no direct evidence for an arid climate. However, we do not think that arid climate prevailed in the latest Carnian to mid-Norian. Based on the argument presented below, a semi-arid climate was interpreted instead, which was definitely dryer than the late Norian to Rhaetian climate. An arid climate is interpreted for the Late Permian deposits of the Transdanubian Range that are made up of cyclic alternation of shallow lagoonal dolomite and evaporitic dolomite (sabkha facies). Pseudomorphs of gypsum are common in the Lower Anisian dolomites. As for the Gémhegy Dolomite and the Fődolomit Fm., the presence of dolocrete horizons may suggest semi-arid climate. According to Wright (2007) most present-day calcretes form in areas with warm to hot climates and low, seasonal rainfall. However, the main point is that the traces of karstification and the clayey palaeosoil horizons, which are typical in the Dachstein Limestone, are completely missing in the pervasively dolomitized segments. These are the main arguments for the upward increasing humidity which is accompanied by the decreasing grade of dolomitization.

Lines 685-686 - Yes, due to the compaction, which significantly reduced the porosity and the permeability to levels too low to sustain a viable convection (Machel, 2004).

We modified the sentence. 


\section{Genesis of Upper Triassic peritidal dolomites in the Transdanubian Range, Hungary}

2

a MTA-ELTE Geological, Geophysical and Space Science Research Group, H-1117 János Haas ${ }^{\mathrm{a}}$, Georgina Lukoczki ${ }^{\mathrm{a}, \mathrm{b}}$, Tamás Budai ${ }^{\mathrm{c}}$, Attila Demény ${ }^{\mathrm{d}}$

Budapest, Pázmány P. sétány 1/c

(E-mail: haas@ludens.elte.hu) Tel: 361 3812127, Fax: 3613812128

${ }^{\mathrm{b}}$ University of Alberta, Department of Earth and Atmospheric Sciences, Edmonton, T6G 2E3, Canada

${ }^{c}$ Geological and Geophysical Institute of Hungary, H-1143 Budapest, Stefánia út 14.

${ }^{\mathrm{d}}$ Institute for Geological and Geochemical Research, Research Centre for Astronomy and Earth Sciences, Hungarian Academy of Sciences, H-1112, Budapest Budaörsi út 45

\section{Abstract}

In the Late Triassic, a 2-3 km thick platform carbonate succession formed along the passive margin of the Tethys Ocean. Certain parts of the succession were affected by pervasive dolomitization whereas other parts are only partially dolomitized or non-dolomitized. In the Transdanubian Range, Hungary, the Upper Triassic platform carbonates are extensively distributed and numerous data are available for the space and time relations of the dolomitized and non-dolomitized units. This geological setting provides a unique opportunity for the study of palaeogeographical and diagenetic controls of dolomitization of the whole platform complex. This paper present the characteristic features of the dolomite-types of the dolomitebearing formations and lithofacies-types, with a view to interpret the dolomite-forming processes and to determine the main controlling factors of the dolomite genesis. Petrographic features and stable isotope characteristics of the studied successions suggest the predominance of penecontemporaneous and early diagenetic dolomite genesis. Study of the transitional interval between the pervasively dolomitized and the non-dolomitized sequences revealed the 
general presence of microcrystalline dolomite in the peritidal microbial deposits and the characteristics of partial dolomitization both in the peritidal and subtidal facies. In the peritidal facies microbially-induced $\mathrm{Ca}-\mathrm{Mg}$ carbonate precipitation is inferred, which was probably complemented by penecontemporaneous mimetic dolomitization of precursor carbonates due to evaporative pumping or seepage influx. Dolomitization of the subtidal facies took place via reflux of slightly evaporated sea-water. Dolomitization of the previously deposited carbonate mud commenced during subsequent subaerial exposure but the process of early diagenetic dolomitization may have continued during later exposure events. Recurring subaerial exposure is one of the controlling factors, determining the areal extent of the early dolomitization of the platform carbonates. However, the climatic conditions were also crucial. Although the sea-level controlled, unconformity-bound cyclic facies pattern did not change significantly in the internal platform belt during the nearly $20 \mathrm{My}$ long time-range, a drier climate favoured dolomite formation while increasing humidity led to a gradual decreasing intensity of early dolomitization.

\section{Keywords}

Dolomite genesis, carbonate platform, depositional cycles, diagenesis, stable isotopes, Upper Triassic, Transdanubian Range, Hungary

\section{Introduction}

In spite of the remarkable efforts made for understanding the dolomite forming processes during the more than 200 years history of dolomite research, several crucial problems of dolomite genesis are not satisfyingly resolved and are subject of intense debate (e.g., Land 1985; McKenzie 1991; Warren 2000; Mazzullo 2000; Machel 2004; Merino and Canals 2011; Gregg et al. 2015). Considering also the particular importance of the processes of 
dolomitization in various fields of applied geology, mostly in reservoir charcterization, it is no wonder that it has been one of the hottest topics in geology for a long time. Inferences of many previous studies suggest that dolomite formation is commonly a multistage process. It is the result of a series of processes starting synsedimentarily or in the course of very early diagenesis on or near to the surface, continuing during burial, with further changes likely taking place on uplift. Overprinting of these processes makes deciphering the evolutionary stages very difficult. Recognition and verification of early dolomite genesis are particularly problematic, in many cases almost impossible. However, from our experience, investigation of transitional successions between dolomitic and non-dolomitic carbonates of otherwise similar sedimentological aspect, commonly encompassing partially and selectively dolomitized rock-types, does provide a good chance for recognition of early elements of the paragenetic succession, and, accordingly, for reconstruction of the earliest stages of the dolomitization history. This may be of critical importance because the early dolomite phases can be templates for later, more pervasive dolomitization (Mazzullo 2000; Machel 2004).

Platform carbonates were widely developed in the area of the Late Triassic western Neotethys margin. Thick Upper Triassic platform dolomite and limestone successions are exposed in the Western Carpathians, Northern Calcareous Alps, Southern Alps, External Dinarides and Hellenides (e.g., Bosellini and Hardie 1985; Jadoul et al. 1992; Ogorelec and Rothe 1992; Iannace and Frisia 1994; Haas et al. 1995, 2012; Gianolla et al. 2003; Dimitrievic and Dimitrievic 1991; Gawlick 2000; Kovács et al. 2011). In the Transdanubian Range, the earlier (Carnian to mid-Norian) stage of the internal platform evolution is represented by a thick dolomite succession progressing upward into a similarly thick limestone succession through a more than $100 \mathrm{~m}$ thick transitional interval. Furthermore, the stromatolitic peritidal beds are commonly partially dolomitized, even in the upper part of the platform carbonate succession made up predominantly of limestone (late Norian to Rhaetian). Accordingly, 
inferences from studies of partially dolomitic rock-types, where the traces of the earliest dolomite-forming processes are not overprinted by the subsequent dolomitization, can serve as a basis for the interpretation of pervasively dolomitized sequences.

\section{Geological setting and palaeogeography}

The Transdanubian Range is located in the north-western part of Hungary (Fig. 1a). Forming a large NE-SW trending synform, it is predominantly made up of Middle and Upper Triassic shallow marine carbonates, developed in 2-3 km thickness (Fig. 1b). The stratigraphic chart of the Upper Triassic of the Transdanubian Range is presented in Fig. 2.

During the early period of the Alpine plate tectonic cycle the Transdanubian Range structural unit was a segment of the Adriatic margin of the western Tethys; it was situated in the neighbourhood of the South Alpine and the Austroalpine domains (Haas et al. 1995). In this region, the opening of the western basin of the Neotethys Ocean commenced in the Middle Triassic. During the late Anisian to earliest Carnian two carbonate platform systems developed in the area of the Transdanubian Range: a large one in the north-eastern part, and a smaller one in the south-western part, separated by a large basin (Haas and Budai 1999). A cyclic dolomite succession (Budaörs Dolomite) was formed in the inner platform, thick, massive beds with dasycladalean algal fragments and/or obscure microbial components alternate with thin laminated microbial boundstone beds. Organogenic synsedimentary dolomitization of this succession took place under a semi-arid climate (Hips et al. 2015). In the large basin between the larger and the smaller carbonate platforms, pelagic cherty limestone with volcanic tuff interbeds was deposited from the middle Anisian until the earliest

Carnian (Budai et al. 1999). This succession is overlain by dark grey marl with siltstonesandstone interlayers (Veszprém Formation) and basinal cherty limestone/dolomite facies 
(Csákberény Formation). This marked lithological change, the increasing kaolinite content (Rostási et al. 2011, Haas et al. 2012) and the sporomorph assemblage (Góczán et al. 1991) indicate a more humid climate. A fall of sea level took place roughly coevally with the Carnian Pluvial Event (CPE) (Haas and Budai 1999), which resulted in subaerial exposure and accordingly the demise of the carbonate platforms. A sea-level rise followed the CPE, which led to re-establishment and then progradation of the carbonate platforms during the late early Carnian highstand period (Haas and Budai 1999). In the internal part of the large platform east of this basin (eastern South Bakony, Vértes Hills), cyclic successions of metrescale alternating peritidal and shallow subtidal dolomite beds were formed in a thickness of 400-500 m (Gémhegy Dolomite Formation). In the vicinity of the city of Veszprém, in the central part of the Bakony Mountains, a $\sim 100 \mathrm{~m}$ thick dolomite succession intercalates into the basinal marl sequence representing the prograding highstand tongue of the Carnian platform (Sédvölgy Member of the Gémhegy Formation).

The basins located in the south-western and central part of the Transdanubian Range were filled by the latest Carnian (Sándorhegy Formation), which resulted in a levelled topography giving rise to the development of a huge platform extending over the area of the former basins (Haas and Budai 1999; Haas et al. 2012). In the north-eastern part of the Transdanubian Range (Buda Hills and Csővár blocks on the eastern side of the Danube), located close to the former ocean-ward platform margin, new intraplatform basins formed in the late Carnian where cherty carbonates of toe-of-slope and basin facies accumulated from the late Carnian onward; pelagic conditions continued into the early Jurassic (Pálfy et al. 2007). On the remaining part of the segmented outer-platform belt, microbial-oncoidal, locally reefal limestones were formed (Remetehegy Member of the Dachstein Formation), predominantly in a subtidal environment during the latest Carnian to latest Norian (Rhaetian?) interval (Haas 2002, 2012). No dolomite conformable to the bedding is known in this unit; however, 
irregular dolomite bodies of decimetre to tens of metre size of late diagenetic, probably hydrothermal origin locally occur (Balog and Haas 1990; Juhász et al. 1995). Behind the external platform belt, in a predominant part of the Transdanubian Range, an extremely wide internal platform belt evolved where ca. $2.5 \mathrm{~km}$ thick cyclic peritidal - shallow subtidal platform carbonates were deposited, i.e., the Födolomit Formation; equivalent of the North Alpine Hauptdolomit and the South Alpine Dolomia Principale (Bosellini and Hardie 1985; Iannace and Frisia 1994; Balog et al. 1999) in the latest Carnian to late Norian, and the Dachstein Limestone Formation in the late Norian to the end of the Rhaetian (Haas 1988; Balog et al. 1997; Haas et al. 2012). The transition between the Fődolomit Formation and the overlying Dachstein Limestone Formation is gradual. The transition is represented by the late Norian Fenyőfó Member of the Dachstein Limestone Formation. It is characterised by an alternation of completely dolomitized, partially and selectively dolomitized, and undolomitized segments (Haas 1995a, 1995b).

It should be noted, however, that the chronostratigraphic subdivision of the Norian-Rhaetian interval is still debated and the definition of the Norian/Rhaetian boundary is underway. Moreover, the subdivision is based on pelagic fossils (primarily on ammonoids, conodonts and radiolarians) and consequently the possibility for correlation between the chronostratigraphic key-sections and the platform carbonate successions is rather limited. The correlation is even more difficult in the cases of the pervasively dolomitized platform carbonates due to the paucity of biostratigraphically useful fossils. The stratigraphic assignment and the correlation of the platform carbonates are based mostly on Megalodont bivalves, foraminifera and dasycladalean algae (Végh-Neubrandt 1982; Oravecz-Scheffer 1987; Budai and Fodor 2008).

In connection with the incipient rifting of the later Alpine Tethys basin, an extensional tectonic regime was established in the western part of the Transdanubian Range during the 
late Norian (Haas and Budai 1995). This extension resulted in the development of a basin in the SW part of the Transdanubian Range where thin-bedded, laminated dolomite formed (Rezi Dolomite). It was followed by the deposition of organic-rich shales (Kössen Formation) reflecting enhanced humidity in the latest Norian-early Rhaetian (Haas 2002; Berra et al. 2010). In the central and NE part of the Transdanubian Range, the building of the carbonate platform continued coevally with the extension and during the late Rhaetian the platform prograded on to the Kössen Basin.

By the end of the Triassic the Gémhegy Dolomite and Födolomit Formation reached the intermediate burial zone (1.0 to $1.5 \mathrm{~km}$ depth). The extensional regime was maintained and differential subsidence continued during the Jurassic into the Early Cretaceous interval, when the Upper Triassic dolomite formations may have reached the deep burial zone (2.0 to $3.0 \mathrm{~km}$ ). An important compressional deformation event occurred in the mid-Cretaceous that resulted in the formation of the large synclinal structure of the Transdanubian Range (Haas 2012). This was followed by uplift and intense erosion during the Turonian to Coniacian interval leading to denudation of the entire Jurassic-Lower Cretaceous succession and even a large part of the Triassic sequence on the limbs of the syncline (Haas 1985, 2012). Consequently, the Upper Triassic platform carbonates were first raised to the surface after their burial at this time. Similar tectonically-controlled uplift, denudation, and fracturing occurred in several stages during the Cainozoic. These multiphase tectonic movements led to disintegration (fracturing, brecciation) of the rigid dolomites and gave rise to intense fluid circulation and related late diagenetic processes (dedolomitization, precipitation of fracturefilling cements and locally hydrothermal minerals, powderization), which totally destroyed the original fabric over large parts of the Transdanubian Range (Esteban et al. 2009; Poros et al. 2013). 


\section{Sampling and methods}

177 Although Upper Triassic dolomites are widely developed at the surface, there are only a few 178 places where the stratigraphic position of the exposed segments is relatively well-constrained 179 and the primary rock properties (bedding, sedimentary-early diagenetic fabrics) are 180 preserved. Thus, special care was taken during the collection of the 31 representative samples 181 from the 8 carefully chosen locations (Fig. 1b) for the present study. Results of earlier studies 182 (Haas 1995a,b; Balog et al. 1999; Haas and Demény 2002) complemented with reinvestigation and re-evaluation of 450 archive thin-sections from the same locations sampled for this study were also used for the interpretation of the dolomite genesis.

The thin-sections were stained with Alizarin red-S and potassium ferricyanide according to the methods of Dickson (1966) for the determination of the carbonate phases. Dolomite texture is described pursuant to the classification scheme presented by Machel (2004).

Cathodoluminescence (CL) study was performed on polished thin-sections using a MAAS-

Nuclide ELM-3 cold-cathode luminoscope at the Department of Physical and Applied Geology, Eötvös Loránd University.

191 Stable isotope measurements $\left(\delta^{18} \mathrm{O}, \delta^{13} \mathrm{C}\right)$ were performed on micro-drilled calcite and 192 dolomite powder samples at the Institute for Geological and Geochemical Research, 193 Hungarian Academy of Sciences according to the methods of McCrea (1950) and Spötl and Vennemann (2003) on a Finnigan delta plus XP mass spectrometer using international and laboratory standards. Mean values of the measurements are reported relative to Vienna Pee Dee Belemnite standard (V-PDB, \%o). Reproducibility was better than $\pm 0.1 \%$.

\section{Lithological and petrographic characteristics}


The studied lithostratigraphic units typically exhibit metre-scale cyclicity. The $1-5 \mathrm{~m}$ thick cycles are mostly bounded by nearly flat or slightly uneven bedding planes. Characteristic lithofacies types of Lofer-cycles were recognized: red to green argillaceous, commonly intraclastic mudstone - Lithofacies A (Lf A); stromatolite (fenestral laminated microbialite) Lithofacies B ( $\mathrm{Lf} \mathrm{B}$ ); and carbonates of various microfacies types with marine biota Lithofacies C ( Lf C).

Although the basic lithofacies types ( $\mathrm{Lf} \mathrm{A}, \mathrm{Lf} \mathrm{B}$, and $\mathrm{Lf} \mathrm{C}$ ) are similar across the studied units, the composition of elementary cycles can be distinct due to differences in the presence or absence of certain lithofacies and their thickness ratio within the elementary cycle (Haas 2004). In the Gémhegy and Födolomit Formations the cycles typically comprise B and C lithofacies types. Thin (few $\mathrm{cm}$ ) red, argillaceous laminated, rarely pisolitic dolocrete (Lf A) occurs above the disconformity (d) (Balog et al. 1997). The ideal cycle pattern is d-B-C-B-d, although truncated cycles are common (Haas 2004). In the lower part of the Fenyoffö Member, the construction of the cycles is similar to that in the Födolomit Formation. In the upper part of the Fenyőfö Member the reddish or greenish argillaceous lithoclastic Lf A commonly appears above the disconformity and the cycle pattern d-A-B-C-B-d becomes prevalent in the lower part of the Dachstein Limestone s.s. (Haas 2004).

\section{Petrographic features}

The most important petrographic characteristics of the studied units are summarized below and in Table 1.

Pervasive dolomitization characterizes all studied successions of the Gémhegy Dolomite and the Födolomit Formations and the lower parts of the cycles in the Fenyöfo Member of the Dachstein Formation. Pervasive dolomitization of the Lf B beds is always fabric preserving, thus fenestral laminated, clotted micritic stromatolite fabrics are readily recognizable. In the 
Lf $\mathrm{C}$ beds the degree of fabric preservation varies between good fabric preservation and complete fabric obliteration. In the samples with preserved fabric, bioclastic wackestone and bioclastic grainstone textures, with bioclasts (usually ghosts of bioclasts), peloids and intraclasts are recognizable. The fabric obliterating dolomites are usually very finely to finely crystalline, exhibiting a predominantly planar-s texture. The crystals usually have cloudy cores and limpid rims showing mottled and very dull CL, respectively.

Partial dolomitization of the Dachstein Formation is either fabric selective or not. If fabric selective, the planar-p dolomite crystals occur in the micritic components (Lf B) or in the finely crystalline matrix ( $\mathrm{LfC}$ ). If not fabric selective, the planar-p dolomite crystals occur in irregular patches. In the partially dolomitized beds the dolomite content usually shows an upward decreasing trend.

Very fine-medium crystalline planar-s dolomite fills the fenestral pores in the Lf B beds and the intergranular pores in the $\mathrm{Lf} \mathrm{C}$ beds, as well as lining the walls of larger vuggy pores and fractures in both the Lf $\mathrm{B}$ and $\mathrm{Lf} \mathrm{C}$ beds. These planar-s dolomites always have a cloudy appearance and mottled CL.

Medium-coarsely crystalline limpid dolomite cement (planar-c) commonly overgrows the planar-s void-filling dolomite and lines fractures; it shows concentric zonation under CL. This dolomite cement-type occurs in both the Lf B and Lf C lithofacies and in both the pervasively and the partially dolomitized sections, except in the Dachstein Limestone s.s.

Blocky calcite cement is the final pore-occluding phase in the Fenyőfo Member and in the Dachstein Limestone s.s. It also occurs in the Fődolomit Formation locally (Csákánykő section, Vértes Hills). This coarsely crystalline calcite is usually non-luminescent, locally with a few bright orange zones. Dedolomite i.e. calcite showing textural features of dolomite, scarcely occurs in the Fenyőfö Member. 


\section{Gémhegy Dolomite Formation}

\section{Disznó Hill Quarry, Vértes Hills}

The Gémhegy Dolomite was studied in a small, abandoned quarry at Disznó Hill, in the SW part of the Vértes Hills (see Fig. 1b;2). The exposed, ca. $15 \mathrm{~m}$ thick succession is made up of an alternation of 0.5 to $1.5 \mathrm{~m}$ thick beds of light brownish grey, finely crystalline dolomite ( $\mathrm{Lf}$ C) and 0.2 to $0.3 \mathrm{~m}$ thick yellowish grey, laminated dolomite beds ( $\mathrm{Lf} \mathrm{B}$ ). A typical complete cycle was selected for the detailed investigation (Fig. 3a). Above an uneven cycle boundary surface, Lf B occurs in the basal part of the cycle which grades upward into Lf C showing pedogenic alteration in its topmost part.

The sedimentary texture of Lf B is perfectly preserved, comprising slightly undulating laminae of clotted micrite with fenestral pores (Fig. 3b-c). The fenestral pores are usually filled by finely to medium crystalline dolomite Similar dolomite crystals line the larger (mmsized) vugs, and coarsely crystalline $(200-800 \mu \mathrm{m})$ dolomite cement (planar-c) occurs in the centre of the pores (Fig. 3d-e). A similar cement fills the fracture network.

The transition between the stromatolite layer ( $\mathrm{Lf} \mathrm{B}$ ) and the overlying massive bed (Lf C) is gradual. Cm-sized stromatolite-derived clasts occur in the lowermost few $\mathrm{cm}$ of the massive bed. The Lf C consists of replacive, fabric-destructive, finely to medium crystalline (50-80 $\mu \mathrm{m})$, non-planar and planar-s dolomite with cloudy cores and limpid rims. The limpid rims show the same CL pattern as seen in the case of the cements of the fabric-preserving dolomite (see Fig. 3e). Planar-c cements occur in open pores (Fig. 3f-g).

The uppermost part of this bed has a relatively well-preserved, although pedogenically altered, bioclastic wackestone texture (Fig. 3h). The biomolds are filled by finely to medium crystalline dolomite similar to the cement types found in the Lf B beds. The mm-sized irregular dissolution and/or root-derived pores are commonly lined by finely laminated 
micrite. The rest of the pore-space is fringed by finely crystalline, cloudy, planar-s dolomite filling voids; coarsely crystalline $(200-400 \mu \mathrm{m})$, dolomite cement (planar- c) occurs in the inner parts of the pores.

\section{Benedek Hill, Veszprém, Bakony Mountains}

The steep wall of Benedek Hill towards Séd Valley is the type locality of the Sédvölgy Dolomite Member (see Fig 1b; 2). The exposed, approximately $20 \mathrm{~m}$ thick Lf C sequence comprises two parts (Fig. 4a). The lower part is predominantly thick-bedded with a few thinner intercalations, whereas the upper part is mainly thin-bedded with thick-bedded intervals. An uneven erosional surface separates the two segments.

The thick-bedded, light grey-yellowish grey, finely crystalline dolomite locally shows a mottled fabric. The dolomite is fabric-destructive; the finely to medium sized $(50-100 \mu \mathrm{m})$ planar-s crystals have cloudy cores and limpid rims (Fig. 4b). The cloudy cores show mottled CL, whereas the limpid rims have very dull red luminescence. The small pores are filled by somewhat coarser $(110-150 \mu \mathrm{m})$, clear, planar dolomite cement. Open pores are also common. In some beds relics of peloidal, bioclastic sedimentary texture are visible (Fig. 4c). The matrix is finely crystalline $(30-80 \mu \mathrm{m})$. The biomolds and vugs are filled by finely to medium crystalline inclusion-poor dolomite. Partly open, mm-sized pores are lined by coarsely crystalline $(300-500 \mu \mathrm{m})$, planar-c dolomite (Fig. 4d).

The upper part of the section comprises an alternation of $0.2-1.0 \mathrm{~m}$ thick beds with sets of $2-$ $5 \mathrm{~cm}$ thick layers of fabric-destructive dolomite. In the very finely to finely crystalline (10-30 $\mu \mathrm{m})$ planar-s matrix ghosts of dasycladalean algae and fragments of molluscs are marked by inclusion-rich crystals (Fig. 4e). The moulds are occluded by medium crystalline (50-200 $\mu \mathrm{m})$ planar-c dolomite. Micritic grains (peloids) also occur rarely (Fig. 4f). 
Fődolomit Formation

\section{Aranyosvölgy Quarry, Bakony Mountains}

303

The abandoned quarry (Fig. 1b;2) exposes a 20 m thick segment of the lower part of the Fődolomit Formation (Fig. 5a).

The cycles are usually bounded by an uneven erosional surface with red clay coating. In the case of the lower investigated cycle, it is overlain by a $20 \mathrm{~cm}$ thick layer of pale reddish-grey colour exhibiting well-preserved pedogenically altered mudstone - wackestone with peloids and bioclasts (Fig. 5b-c). The fracture network and the irregular pores are filled by very finely to finely crystalline dolomite. The larger vuggy pores are usually only partly filled by coarsely crystalline planar-c dolomite. The basal layer is overlain by a $1 \mathrm{~m}$ thick bed ( $\mathrm{Lf} \mathrm{C}$ ) showing a relatively well-preserved wackestone texture with 0.1 to $3 \mathrm{~mm}$ sized grains (peloids, lumps, micritic intraclasts), and their ghosts in the lower part of the bed. The distinct grains gradually disappear upward and a very finely crystalline texture becomes prevalent with beddingparallel elongated pores which are occluded by fine to medium crystalline $(50-150 \mu \mathrm{m})$ planar-c dolomite. Medium crystalline, cloudy, planar-c cement occurs as the final cement phase in larger (0.5-2 mm-sized) vugs as a clear overgrowth on the cloudy cements (Fig. $5 \mathrm{~d}-$ e).

In the case of the upper studied cycle (see Fig. 5), a stromatolite (Lf B) occurs directly above the cycle bounding unconformity. The basal part of this bed exhibits a clotted micritic fabric (Fig. 5f). The 200 to $400 \mu \mathrm{m}$-sized fenestral pores are filled by very finely crystalline dolomite. The larger pores (fenestrae, moulds and vugs) are filled by medium crystalline (150 $-250 \mu \mathrm{m}$ ) planar-c dolomite (Fig. 5g). Intraclast-bearing and peloidal grainstone laminae are also present (Fig. 5h). 
The typical laminated Lf B grades upward into a non-laminated fabric (Lf C). Micritized grains, 2 to $5 \mathrm{~mm}$-sized micrite nodules and ghosts of skeletal fragments are common (Fig. 5i). The smaller irregular intergranular pores are occluded by very finely crystalline dolomite, the larger ones by finely crystalline planar-c dolomite. The mm-sized vugs are filled by medium to coarsely crystalline planar-c dolomite.

\section{Horogvölgy exposure, Vértes Hills}

A road-cut exposes a ca. $10 \mathrm{~m}$ thick segment of the middle part of the Födolomit Formation (see Fig. 1b, 2). The metre-scale cycles are made up of a cyclic alternation of Lf B and Lf C.

The Lf B is characterized by a clotted micritic fabric with faint microlamination (Fig 6a). There are well-defined, thin, undulating micritic crusts containing 50-150 $\mu \mathrm{m}$-sized spherical objects with micritic contours (microproblematicum Thaumatoporella?) (Fig. 6b). In some fenestral pores typical Thaumatoporella were encountered. The fenestral pores are occluded by finely crystalline, planar-s dolomite. The larger pores are lined by medium crystalline planar-c dolomite (Fig. 6c-d).

The Lf $\mathrm{C}$ exhibits bioclastic grainstone texture. The micrite components and micritic envelopes around the biomolds are preserved. The matrix is usually replaced by very finely crystalline cloudy dolomite and the small intergranular pores are occluded by finely crystalline $(20-60 \mu \mathrm{m})$ planar-s dolomite. The large moulds are filled by medium crystalline $(50-250 \mu \mathrm{m})$ planar-c dolomite. The fractures are lined by medium crystalline planar-c dolomite and filled by coarsely crystalline $(500-1000 \mu \mathrm{m})$ blocky calcite, which is the final cement phase also in some moulds (Fig. 6e-f).

\section{Csákánykö Quarry, Vértes Hills}


The abandoned quarry exposes a $5 \mathrm{~m}$ thick peculiar interval of the uppermost part of the

349 Fődolomit Formation (see Fig 1, 2). The succession is dominated by thick stromatolite beds

350

351

352

353

354

355

356

357

358

359

360

361 (Lf B) (Fig. 7a).

The Lf B beds consist of undulating laminae of $\mathrm{mm}$ - to $\mathrm{cm}$-thick yellow and light grey finely crystalline dolomite with many mm-sized pores predominantly in the yellow laminae (Fig. 7b). Alternation of thin laminae of dense micrite and clotted peloidal micrite is visible under the microscope (Fig. 7c). Millimetre-sized stromatolite intraclasts (rip-up breccia) occur at some horizons. Domical structures (Fig. 7d), remnants of microbial structures (moulds of filaments and globular objects filled by very finely crystalline dolomite) also appear. The fenestral pores are filled by very finely to finely crystalline dolomite and/or coarsely crystalline blocky calcite. Similar dolomite cement appears in the fracture network and as a lining in the larger vug pores (Fig. 7e). The centres of these pores are either occluded by coarse blocky calcite or are open.

The thin Lf C bed intercalated into the thick stromatolite interval consists of light brownish grey, massive, very finely crystalline dolomite. It contains scattered peloids and micritic intraclasts as relic elements in the microsparite matrix (Fig. 7f). The $1 \mathrm{~m}$ thick Lf C bed, lying directly above the stromatolitic interval exhibits a well-preserved sedimentary fabric abundant in peloids, and micritic intraclasts (Fig.7g). Scattered ghosts of bivalves and gastropods can also be encountered. The matrix consists of very fine to finely crystalline planar-s dolomite. The biomolds are filled by finely crystalline planar-c dolomite.

\section{Dachstein Limestone Formation, Fenyőfö Member}

\section{Epöl Quarry, Gerecse Mountains}


The Epöl quarry located within the village (see Fig. 1b) exposes a ca. 45 m-thick section of the upper part of the Fenyőfo Member (Fig. 2). Detailed investigation of the section was carried out by Haas and Demény (2002). Their results were complemented by the study of newly collected samples.

The succession is made up of disconformity-bounded metre-scale cycles (Fig. 8a). A 10-20 cm-thick greenish laminated, intraclastic horizon (laminar and breccia dolocrete) (Lf A), and/or a 10-50 cm-thick laminated layer ( $\mathrm{Lf} B$ ) occur at the base of the cycles. The Lf A beds consist of dolomicrite-microsparite and exhibit mm-scale definite to vague lamination (Fig. 8b). Cm-sized dolomicrite clasts are common at certain horizons (Fig. 8c). The Lf B beds show wavy lamination, locally with $\mathrm{cm}$-sized domical structures. The matrix is clotted micrite with patchy brownish staining. Fenestral laminated structures and sheet-cracks with geopetal filling are common (Fig. 8d; e). The fenestral pores are rarely fringed by small euhedral dolomite crystals and are generally filled by blocky calcite. At the bottom of the larger fenestral pores and sheet cracks, dolomite silt internal sediment occurs below the blocky calcite cement.

The basal cycle members (Lf A and B) are overlain by a 1-4 m-thick finely crystalline, usually partially dolomitized limestone bed with blocky calcite spar-filled moulds of megalodonts (Lf C). Generally the lowermost and the uppermost 10-30 cm thick parts of the Lf C beds were affected by intense dolomitization. The basal part of the investigated beds (see Fig. 8a) is almost completely dolomitized, only the echinoderm fragments remained calcite (Fig. 8f). The dolomite is fabric-destructive; in the finely crystalline planar-s dolomite matrix only a few peloids and micritic intraclasts were encountered. The degree of dolomitization gradually decreases upward. In the upper part of the bed, scattered euhedral (planar-p) dolomite crystals occur in the otherwise undolomitized micrite matrix (Fig. 8g-h). The smaller biomolds (after foraminifera) are filled either by dolomite or calcite, the larger 
biomolds by coarsely crystalline planar-c dolomite with calcitized (dedolomite) zones (Fig. 8i) and/or blocky calcite.

\section{Core sections from Ugod and Porva, Bakony Mountains}

In the area of the Northern Bakony Mountains the cyclic Fenyőfö Member can be subdivided into three parts. The lower and the upper parts are made up of alternating cycles of limestone, partially dolomitic limestone and dolomite beds. In the upper part the dolomite and dolomitic limestone rock-types are dominant, but the ratio of the limestone intervals increases upward. The middle part is almost exclusively dolomite. Previous investigation of the Fenyőfo Member was performed by Haas (1995a) and Balog et al. (1999) on core samples from the boreholes Ugod Ut-8 and Porva Po-89 (see Fig. 1b; 2). The cyclic lithofacies changes and the variations in the dolomite content are displayed on Figs. 9 and 10. The most important features of these successions are summarized below based on previous studies (Haas 1995a; Balog et al. 1999) and new results of the current study.

Appearance of $0.3-0.5$ m-thick red or green dolomitic marl or lithoclastic limestone layers (Lf A) is the most prominent feature of the lower part of the Fenyőfö Member. The stromatolite beds (Lf B) showing fenestral laminated fabric are predominantly made up of dolomite. The matrix is clotted microcrystalline dolomite. The fenestral pores are usually lined by a very thin cement layer consisting of planar-c limpid dolomite rhombs $(10-80 \mu \mathrm{m})$. The internal part of these pores is occluded by coarsely crystalline blocky calcite (Fig. 11a-b). Amalgamated fenestrae, cm-sized sheet-cracks, are common. Dolomite and calcite silt and micrite occur at the base of these large pores; the remaining pore space is partially filled by finely to coarsely crystalline planar-c dolomite, dedolomite and/or coarsely crystalline blocky calcite cement. 
The Lf C beds are either completely or partially dolomitized or undolomitized. In some cases scattered euhedral dolomite rhombs (planar-p) appear mostly in micritic fabric elements (peloids, micritic envelopes of bioclasts) (Fig. 11c). In other cases mouldic pores are filled by finely crystalline planar-c dolomite. Fabric-destructive replacive dolomite also commonly occurs. In these cases the grade of dolomitization varies in a wide range from $40-50 \%$ to nearly $100 \%$ dolomite content (Haas 1995a). In the partially dolomitized textures the finely crystalline planar-s dolomite appears in irregular patches (Fig. 11d). In many cases only a part of the Lf C beds (usually their lower part) was affected by dolomitization.

\section{Dachstein Limestone Formation (s.s.)}

In the key core section Porva Po-89, above the Fenyöfö Member, in the lower part of the Dachstein Limestone (Norian), the dolomite content of the usually stromatolitic Lf B is between 5 to $80 \%$ (Haas 1995a), but Lf C is usually dolomite-free or contains only small amounts of tiny planar-p dolomite rhombs, preferentially in the micritic fabric elements (micritized bioclasts, peloids) of packstone/grainstone. In the upper part of the Dachstein Limestone (Rhaetian) the dolomite content of Lf B is usually $<10 \%$ (Haas 1995a). The present study focuses on the lowermost part of the Dachstein Limestone (s.s.) investigated in the core Po-89 (Fig.10). In the non-dolomitized Lf C small dolomite intraclasts were encountered rarely (Fig. 12a). In the typically stromatolitic Lf B beds the clotted micrite fabric is usually dolomitic (partially or completely), whereas the fenestral pores are occluded by blocky calcite cement. However, in some cases dolomite fringing cement (planar-c) appears on pore walls (Fig. 12 b). The larger pores, which may have formed by merging of fenestral pores, are usually partially filled by dolomite or calcite silt- and mud internal 
sediment, and coarsely crystalline blocky calcite occludes the remnant pore space (Fig. 12c-

d).

\section{Stable carbon and oxygen isotopes}

The results of the stable isotope analyses are presented in Table 2 and Fig. 13. Separate measurement of the matrix and the cement was performed where possible. However, in the case of the samples showing good-medium fabric preservation separate sampling of the matrix and the cement in small pores (framework pores in Lf B and intergranular pores in Lf

C) was not possible. The samples taken from the internal platform facies of the Gémhegy

Dolomite in the Vértes Hills exhibiting various fabric types from well-preserved to fabric destructive yielded $\delta^{18} \mathrm{O}$ values between +1.2 and $+1.9 \%$ and $\delta^{13} \mathrm{C}$ values between +2.9 and

$457+3.8 \%$. The $\delta^{18} \mathrm{O}$ values of 2 measured cement samples range from -0.4 to $-3.9 \%$. Values of 458 $\delta^{18} \mathrm{O}+0.5$ to $+0.6 \%$, and $\delta^{13} \mathrm{C}+3.1$ to $3.2 \%$ were measured on samples of obliterated and poorly preserved fabric from the slope and platform facies of the same formation (Gémhegy

Dolomite, Sédvölgy Member) sampled in Veszprém. One dolomite cement sample yielded $\delta^{18} \mathrm{O}-0.7 \%$ and $\delta^{13} \mathrm{C}+2.4 \%$ values.

The samples representing the lower (late Carnian) part of the Födolomit Formation in Veszprém showing good and poor fabric-preservation yielded $\delta^{18} \mathrm{O}$ values between +1.1 and $+2.4 \%$ and $\delta^{13} \mathrm{C}$ values +2.9 to $+3.2 \%$, whereas $\delta^{18} \mathrm{O}-0.0$ to $-0.8 \%$; and $\delta^{13} \mathrm{C}+2.9$ to $3.0 \%$ o were measured on cement.

466 The sample group taken from the uppermost (early late Norian) part of the Födolomit Formation (Vértes Hills) showing good to medium fabric preservation provided the most positive $\delta^{18} \mathrm{O}$ values $\left(+1.6\right.$ to $+3.1 \%$ ) and least positive $\delta^{13} \mathrm{C}$ values $(+1.7$ to $+2.7 \%$ ) 
The dolomite samples of the basal transitional member of the Dachstein Limestone (Fenyőfö Member) exhibiting well-preserved fabric yielded $\delta^{18} \mathrm{O}$ values between -1.0 and $+1.2 \%$ and $\delta^{13} \mathrm{C}$ values between +1.2 and $+3.6 \%$

Inferences of the isotope studies are as follows:

1. There is no significant relationship between the degree of fabric-preservation and the isotope values. Differences in the sedimentary fabric are not reflected in the isotope values, either.

2. The $\delta^{18} \mathrm{O}$ values of both the Gémhegy and the Födolomit Formations are scattered within a narrow range in the positive domain from 0.5 to $3.1 \%$. The upper part of the Födolomit Formation is presented by slightly more positive values than those of the Gémhegy Dolomite and the lower part of the Fődolomit Formation.

3. The $\delta^{18} \mathrm{O}$ values for the Fenyofö Member are compatible with the transitional features of this unit between the Födolomit and the Dachstein Formations (Fig. 14).

4. The $\delta^{13} \mathrm{C}$ values range from +1.2 to $+3.8 \%$ within the range of the Carnian to Norian sea-water (Korte et al. 2005). This range may reflect changes in the C isotope composition of the sea-water (chemostratigraphic signal).

5. The $\delta^{18} \mathrm{O}$ values of cements are always depleted compared to the matrix values; the difference is 1 to $5 \%$. The $\delta^{13} \mathrm{C}$ values do not differ significantly from those of the matrix.

\section{Interpretation of depositional environments and processes of dolomite genesis}

\section{Cyclic deposition and dolomite formation}

The studied dolomite-bearing successions were formed in the protected internal parts of large carbonate platforms characterized by cyclic deposition. No synsedimentary/early diagenetic 
dolomite is known in the coeval predominantly subtidal external platform carbonate successions (Remetehegy Member of the Dachstein Limestone) suggesting that the depositional environment and the conformable synsedimentary/early diagenetic processes are the main controlling factors on the dolomitization of the inner platform carbonates (Fig. 14). Metre-scale, subaerial unconformity bounded cycles (Lofer cycles) consisting of alternating peritidal and shallow subtidal facies make up the internal platform successions (Haas 1988; 2004; Balog et al. 1999; Haas and Budai 1999). Numerous authors have attributed the cyclic nature of the Upper Triassic carbonate formations to orbitally-forced sea-level oscillations (e.g., Sander 1936; Fischer 1964; 1991; Haas 1982, 1991, 1994, 2004; Schwarzacher and Haas 1986; Balog et al. 1997; Cozzi et al. 2003). Others have argued against orbital forcing and suggested an autocyclic peritidal depositional model taking also into account the role of the tectonic activity (e.g., Satterly and Brandner 1995; Satterly 1996; Enos and Samankassou 1998). According to Strasser (1991) both autocyclic and allocyclic cycles display a shallowing-upward trend up to supratidal facies, but definite erosion and intertidal, supratidal or terrestrial overprinting on subtidal facies indicate sea-level fall and autocyclicity, accordingly.

In the case of the Dachstein Limestone the recurring subaerial exposures led to consolidation of the previously deposited sediment via meteoric diagenesis, which was followed by karstic erosion and development of clayey palaeosoils under terrestrial conditions. These features suggest orbitally-driven allocyclic control (Haas 2004). The gradual transition between the Födolomit and Dachstein Limestone may justify the extrapolation the allocyclic model for the entire Late Triassic platform evolution. However, common controlling effects of the sea-level changes and the autocyclic processes cannot be excluded. According to previous studies, the elementary cycles reflect ca. 20 ka precessional periodicity (Schwarzacher and Haas 1986). As a result of the lack of extensive continental ice sheets during the studied time interval 
519 (Frakes et al. 1992), the sea-level fluctuations probably had only several metres amplitude 520 (Balog et al. 1997).

521 The cyclic depositional process can be interpreted according to the following scenario: sea522 level fall (several metres) resulted in subaerial exposure of large parts of the previously 523 inundated platform. After a short exposure period, the rising sea-level led to development of 524 peritidal conditions with stromatolite formation ( $\mathrm{Lf} \mathrm{B}$ ) on the extensive tidal-flat, followed by 525 the establishment of shallow subtidal environments ( $\mathrm{Lf} \mathrm{C}$ ). However, in many cases only subtidal deposits were preserved, usually with some basal lag deposits (reworked clasts derived from the underlying bed). Deceleration and cessation of sea-level rise resulted in upward shallowing and re-appearance of peritidal environments usually covered by microbial mats (Lf B). The next sea-level fall resulted in subaerial exposure and related denudation and truncation of the previously deposited cycle.

According to previous studies (Haas 1995b; Balog et al. 1999) dolomite in Lf B samples yielded $\delta^{18} \mathrm{O}$ values near $+1 \%$ in the lower part of the Dachstein Limestone s.s. (Norian), whereas calcite in the practically undolomitized Lf B in the upper part of the Dachstein Limestone (Rhaetian) yielded values of -1.0 to $-2.1 \%$. $\delta^{18} \mathrm{O}$ values of calcite in the undolomitized $\mathrm{Lf} \mathrm{C}$ range from $-0.4 \%$ to -2.7 in the lower and upper parts of the Dachstein Limestone (see Fig. 14). These values are consistent with the published values of Triassic marine calcite cements (Veizer 1983; Lohman and Walker 1989; Hoffman et al. 1991) and

539 values measured on the marine cements of the Dachstein Limestone in the Transdanubian 540 Range (Balog et al. 1999). Thus the dolomite values of ca. 1\%o of Lf B show a 2 to 3\%o 541 positive shift, in accordance with the inferences of studies on coexisting calcite and dolomite 542 in modern environments (e.g., Aharon et al. 1977; McKenzie 1981; Mullins et al. 1985) and theoretical calculations (Land 1986). This suggests that refluxing marine water was most 
544 likely the dolomitizing agent. Furthermore, the spatial association between the microbial 545 fabrics and the occurrence of microcrystalline dolomite in the fabric selectively dolomitized sections suggests microbially-induced precipitation of $\mathrm{Ca}-\mathrm{Mg}$ carbonates, metastable

547 precursor phases to dolomite (see Vasconcelos and McKenzie 1997; Wright 2000; SanchezRoman et al. 2008; Bontognali et al. 2010; Spadafora et al. 2010). However, there is no direct evidence for microbially-induced dolomitization in this study.

In the Fenyőfő Member, Lf B has a high dolomite content or is pervasively dolomitized, whereas Lf $\mathrm{C}$ is commonly dolomitized to various degrees. In the Lf $\mathrm{B}$ beds the clotted micrite is predominantly dolomite and fringing dolomite cement lines the fenestral pores, which are filled mostly by blocky calcite cement, less commonly by coarsely crystalline dolomite. Dolomitization of Lf C is commonly partial, fabric-selective in the case of lowgrade dolomitization, and patchy or pervasive fabric-destructive in the cases of high-grade dolomitization. In other cases only a part (usually the lower segment) of the Lf C-bed is dolomitized, its upper part is undolomitized. In the Epöl section in the limestone interval of an Lf C bed, $\delta^{18} \mathrm{O}$ is $-1.1 \%$, similar to the typical Dachstein Limestone, whereas the dolomite interval yielded $+0.3 \%$. These textural observations and isotope data suggest that in the $\mathrm{Lf} \mathrm{B}$, the dolomitization of the microbial fabric was followed by the formation of dolomite cement in the fenestral pores, which probably coincided with the onset of replacive dolomitization of the underlying, still unlithified subtidal carbonate sediment (Lf C).

The Fenyőfö Member differs from the Födolomit Formation mostly in the grade of dolomitization, the latter being pervasively dolomitized. Lack of Lf A in the Fődolomit Formation marks another difference. In Lf B of the Födolomit Formation the small fenestral pores are completely filled by finely crystalline dolomite formed either coeval with the very early dolomitization of the microbial mat or in the course of early reflux dolomitization. Lf C was affected by fabric-preserving or fabric-destructive replacive reflux dolomitization. These 
early dolomite-forming processes were commonly followed by dissolution creating vuggy pores both in the Lf $\mathrm{B}$ and $\mathrm{Lf} \mathrm{C}$ layers during the next exposure episode and precipitation of finely to medium-crystalline fringing cement in the pores subsequently. In the uppermost part of the Födolomit Formation $\delta^{18} \mathrm{O}$ values of both lithofacies types scatter in a narrow range from +1.1 to $+2.5 \%$. Similar values in a range from +0.5 to $+2.5 \%$ characterise the lower part of the Födolomit Formation and the Gémhegy Dolomite as well (see: Fig. 13). These values suggest marine, probably slightly evaporated sea-water as the dolomitizing agent. Very similar $\delta^{18} \mathrm{O}$ values $(+0.6$ to $+3 \%$ ) were measured on the very finely crystalline earliest mimetic dolomite generation of the Dolomia Principale in the Southern Alps, and based on these data near-surface low-temperature dolomitization was interpreted (Frisia 1994). According to Meister et al. (2013) abundance of dolomitic stromatolitic and mat-like lamination in the Dolomia Principale suggest a microbial influence, although they noted that there is no direct evidence for the microbially-mediated dolomite formation.

According to the above presented observations and inferences, the mechanism of early dolomite formation in the internal part of large carbonate platforms did not change significantly during the late Triassic. Thus, the dolomitization mechanism for the Upper Triassic cyclic peritidal carbonates is interpreted as follows: During the high-frequency sealevel oscillations, cessation of sea-level rise resulted in progradation of the tidal flats and formation of microbial/organogenic dolomite within the intertidal/supratidal microbial mat. The subsequent sea-level fall led to subaerial exposure of a predominant part of the internal platform and reflux of the slightly evaporated sea-water caused the dolomitization of the semi-consolidated, high-permeability sediment, which was deposited during the previous rising and highstand sea-level period.

\section{Climatic control on dolomitization}


The early dolomitization mechanism of the peritidal carbonates is interpreted to be the same throughout the late Triassic in the Transdanubian Range; however, a remarkable decrease can be recognised in the grade of dolomitization upward in the sequence from the pervasively dolomitized Gémhegy and Fődolomit Formations through the partially dolomitized Fenyőfö Member to the practically undolomitized Dachstein Limestone Formation s.s.(Fig. 14) This trend can be attributed to a long-term climatic change, i.e., increasing humidity during the early late Norian to Rhaetian (Iannace and Frisia 1994; Balog et al. 1997, 1999; Berra et al. 2010; Haas et al. 2004; 2012, Berra 2015).

In the Late Triassic the studied region was located in the tropical climatic belt, moving from $18^{\circ} \mathrm{N}$ to $25^{\circ} \mathrm{N}$ from the early Carnian to the late Norian (Marcoux et al. 1993; Berra 2015). The predominantly zonal climate (Kent and Olsen 2000) was modified by the global-scale mega-monsoon that generated a seasonal climate along the coasts progressing continent-ward to semiarid - arid climate (Kutzbach and Gallimore 1989; Preto et al. 2010). This long-term climatic setting was interrupted by a humid episode in the late early Carnian (Carnian Pluvial Event - CPE) (Simms and Ruffel 1989; Preto et al. 2010; Roghi et al. 2010; Dal Corso et al. 2015).

A significant sea-level fall was demonstrated in the Southern Alps, coeval with or directly after the CPE in the Southern Alps (Berra, 2015; Gattolin et al. 2015). A similar process may have taken place in the Transdanubian Range, which led to the demise of the late Anisian early Carnian platforms (Budaörs Dolomite). The sea-level fall was followed by the onset of the platform construction of the Gémhegy Dolomite during the next sea-level rise (Fig. 14). As a result of the problems of the stratigraphic correlation between the basin and platform facies, the exact relation of the Gémhegy Dolomite with the CPE is uncertain, but most probably it is younger than the humid interval. 
The predominantly dry (semi-arid) climate continued after the CPE. A long-term trend of increasing humidity was recognized in the area of the Transdanubian Range from the late Norian, which shifted into a definite humid episode by the Rhaetian (Haas et al. 2012) (see Fig. 14). The latter abrupt change is well-documented in the Kössen Basin where the deposition of basinal dolomite (Rezi Dolomite) was followed by the deposition of organicrich shales (Kössen Formation). Synchronously, a similar facies change occurred in the Riva di Solto Basin in the Southern Alps (Berra and Cirilli 1997). The end of the Dolomia Principale/Hauptdolomit deposition is attributed to this climatic change and a related significant sea-level fall (Berra et al. 2010). In the Southern Alps, as a result of the sea-level fall an erosional unconformity occurs on the top of the platforms that is covered by terrestrial deposits formed prior to the deposition of the Rhaetian shallow-marine limestones. Consequently, the latest Norian in the Southern Alps has no marine record but it is recorded in the succession of the Transdanubian Range (Balog et al 1997).

The semi-arid climate prevailing from the Late Carnian to the Late Norian may have been optimal for microbial/organogenic dolomite formation and the circulation of slightly evaporated (mesohaline) sea-water could maintain the Mg supply (Jones and Xiao 2005) and thus could have resulted in pervasive dolomitization. Increasing humidity in the early Late Norian decreased the intensity of evaporation and thus decreased the effectiveness of circulation, which is reflected in the partial dolomitization of Lf C-beds as opposed to earlier pervasive dolomitization under more arid climatic conditions. The appearance of thin argillaceous palaeosoil layers (Lf A - palaeosoil horizon or commonly reworked palaeosoil components at the base of the cycles) in connection with the more humid climate may have served as local aquitard horizons and may explain the more pronounced dolomitization of the lower part of some layers. Later on, the progressing humidity led to restriction of the early dolomite formation to the stromatolitic intervals of the typical Dachstein Limestone. 
643 Summing up, it can be concluded that the recurring subaerial exposure is a particularly important controlling factor on the synsedimentary and early dolomite formation, but it is not sufficient in itself. Since the sea-level controlled unconformity-bounded cyclic facies pattern did not change significantly during the studied time range, the upward decreasing grade of dolomitization seems to be related to the change in the climate conditions: the drier climate favoured dolomite formation while later the increasing humidity led to gradually decreasing intensity of the early dolomitization processes. The increasing humidity was also manifested by enhanced meteoric dissolution and by the appearance of clayey palaeosoil horizons in the latest Triassic.

\section{Burial diagenetic and telogenic processes}

Development of the Dachstein platform came to an end by drowning at the Triassic/Jurassic boundary in the NE part, and at the end of the Hettangian in the SW part of the Transdanubian Range. By this time, as a result of continuous thermal subsidence of the Tethys margin the Carnian platform carbonates reached about 1.5-2 km burial depth (Haas and Budai 1995). However, the measured $\delta^{18} \mathrm{O}$ values $(+0.5$ to $+2.5 \%)$ do not indicate burial replacive dolomitization or wholesale dolomite recrystallization at an elevated burial temperature neither in the pervasively, nor in the partially dolomitized units. Consequently, the essentially climatically controlled and thereby stratigraphically determined dolomitization pattern was preserved in the course of burial although the progressively rising temperature during burial led to local recrystallization.

Incipient rifting of the later Alpine Tethys commenced in the SW part of the Transdanubian Range in the Late Norian (Haas and Budai 1995). These tectonic processes led to fracturing and created conduits for fluids resulting in local dissolution. It was followed by precipitation of coarsely crystalline dolomite cement in the central parts of some larger pores and in 
668 fractures. Relatively negative $\delta^{18} \mathrm{O}$ values of these dolomite cements (Fig.13) indicate 669 somewhat elevated temperature (higher than those interpreted for the early dolomite). 670 However, the lack of saddle dolomite in the studied samples suggests that the precipitation 671 temperatures were lower than 60 to $80^{\circ} \mathrm{C}$ (Spötl and Pitman 1998). Thus the cement 672 precipitation may have taken place in shallow to intermediate burial settings.

673 The differential subsidence continued during the Jurassic into the Early Cretaceous interval, 674 when the studied formations reached the deep burial zone (2.5 to $3.0 \mathrm{~km})$. At this depth the 675 compaction significantly reduced the porosity and permeability of the carbonates which 676 hampered the viable circulation of the dolomitizing fluids (see Machel 2004).

677 A significant compressional deformation event occurred in the mid-Cretaceous that resulted in 678 the formation of the large synclinal structure of the Transdanubian Range (Haas 2012). This 679 was followed by uplift and intense erosion during the Turonian to Coniacian interval that resulted in the denudation of the entire Jurassic-Lower Cretaceous succession and even a

681 large part of the Triassic sequence on the limbs of the syncline. Therefore, after burial the Upper Triassic platform carbonates were first raised to a near-surface position at this time. Similar tectonically-controlled uplift, denudation, and fracturing occurred in several stages during the Cainozoic. As a result of to these processes the thick platform carbonate complex was affected by karstification resulting in local dedolomitization and precipitation of calcite in fractures and cavities.

\section{Conclusions}

1. Synsedimentary and early diagenetic processes led to the formation of dolomite in the wide internal zone of the Late Triassic carbonate platforms of the Transdanubian Range, where high-frequency sea-level oscillations resulted in the deposition of unconformity bounded metre-scale peritidal - lagoonal cycles. No early dolomites have 
been found in the coeval deposits of the permanently subtidal external platform belt. Thus, the recurring subaerial exposure appears to be an important controlling factor on the early dolomite formation.

696

697

2. Fabric-selective dolomitization of the laminated microbial deposits of the partially dolomitized Fenyőfő Member and Dachstein Formation s.s. suggests microbiallyinduced precipitation of $\mathrm{Ca}-\mathrm{Mg}$ carbonates, metastable precursor phases to dolomite. It was probably complemented by penecontemporaneous mimetic replacement of precursor carbonates via evaporative pumping or seepage influx closely related to the arid climatic conditions during the late Carnian to late Norian.

3. Dolomitization of the subtidal facies took place via reflux of slightly evaporated seawater during the subaerial episode succeeding their deposition; however, the conditions for early diagenetic dolomitization may have been re-established during later exposure events, which in turn may have resulted in the completion of the dolomitization of the subtidal facies.

4. Since the sea-level controlled unconformity-bounded cyclic facies pattern did not change significantly during the entire studied time range, the upward decreasing dolomite content of the partially dolomitic Fenyöfö Member and the practically nondolomitized Dachstein Limestone s.s. suggest that the increasing humidity may have led to gradually decreasing intensity and finally almost complete cessation of the early dolomitization processes by the latest Triassic (latest Norian to Rhaetian).

5. The extensional tectonic regime from the latest Norian to the Middle Jurassic created fracture porosity when the Upper Triassic platform carbonates reached the intermediate to deep burial zone. Fracturing gave rise to dissolution which was followed by precipitation of dolomite cement in fractures and voids. 
6. The results of this study demonstrate the importance of investigating the transition between dolomitized and non-dolomitized intervals of cyclic platform carbonates. These inferences are applicable for the evaluation of platform dolomite genesis under similar palaeogeographic conditions elsewhere in the stratigraphic record.

\section{Acknowledgement}

The authors thank the editor-in-chief Maurice E. Tucker and the anonymous reviewers for their valuable and helpful comments and suggestions, and the editorial handling of the paper. The present study was supported by the Hungarian National Science Fund (OTKA) grant K 81296 (J. Haas).

\section{References}

Aharon JD, Kolodny Y, Sass E (1977) Recent hot brine dolomitization in the "solar lake", Gulf of Elat, isotopic, chemical and mineralogical study. J Geol 85:27-48

Balog A, Haas J (1990): Sedimentological features and diagenesis of the Dachstein Limestone of the Nagyszál Mt. at Vác. Földtani Közlöny 120: 11-18.

Balog A, Haas, Read JF, Coruh C (1997) Shallow marine record of orbitally forced cyclicity in a Late Triassic carbonate platform, Hungary. J Sed Res 67:661-675.

Balog A, Read JF, Haas J (1999) Climate-controlled early dolomite, Late Triassic cyclic platform carbonates, Hungary. J Sed Res 69:267-282.

Berra F (2012) Sea-level fall, carbonate production, rainy days: How do they relate? Insight from Triassic carbonate platforms (Western Tethys, Southern Alps, Italy) Geology 40:271274. 
Berra F, Angiolini L (2014) The evolution of the Tethys region throught the Phanerozoic: A brief tectonic reconstruction. in: Marlow L, Kendall C, Yose I. eds. Ptroloum systems of the Tethyan region. AAPG Memoir 106:1-27.

Berra F, Cirilli S (1997) Palaeoenvironmental interpretation of the Late Triassic Fraele Formation(Ortles Nappa, Austroalpine Domain, Lombardy) Riv It Paleont Strat 103:53-70

Berra F, Jadoul F, Anelli A (2010) Environmental control on the end of the Dolomia Principale/Hauptdolomit depositional system in the central Alps: Coupling sea-level and climate changes. Paleaogeogr Palaeoclimatol Plalaeoecol 290:138-150.

Bontognali TRR, Vasconcelos C, Warthmann RJ, Bernasconi SM, Dupraz Ch, Strohmenger ChJ, McKenzie JA (2010) Dolomite formation within microbial mats in the coastal sabkha of Abu Dhabi (United Arab Emirates). Sedimentology 57:824-844

Bosellini A, Hardie LA (1985) Facies e cicli della Dolomia Principale delle Alpi Venete. Mem. Soc Geol It 30:245-266.

Budai T, Császár G, Csillag G, Dudko A, Koloszár L, Majoros G (1999) Geology of the Balaton Highland. Budapest, Geological Institute of Hungary, Occasional papers 197.

Budai T, Fodor L (eds) (2008) Geology of the Vértes Hills. Explanatory Book to the Geological Map of the Vértes Hills (1:50 000)]. Budapest, Geological Institute of Hungary, $368 \mathrm{p}$

Cozzi A, Hinnov LA, Hardie LA (2003) Facies and cyclostratigraphy of Dachstein Limestone in the Julian Alps (N.E. Italy): new insight on the Lofer Cyclothem controversy. In: Abstracts of field symposium on Triassic geochronology and cyclostratigraphy. September 2003, St Christina , Italy, p 33

Dal Corso J, Gianolla P, Robert J. Newton RJ, Franceschi M, Roghi G, Caggiati M, Raucsik B, Budai T, Haas J, Preto N (2015) Carbon isotope records reveal synchronicity between 
carbon cycle perturbation and the "Carnian Pluvial Event" in the Tethys realm (Late Triassic). Global and Planatary Change 127:79-90.

Dickson JAD (1966) Carbonate identification and genesis as revealed by staining. J Sed Petrol 36:491-505.

Dimitrijević MN, Dimitrijević MD (1991) Triassic carbonate platform of the Drina-Ivanjica element (Dinarides). Acta Geol Hung 34:15-4Enos P, Samankassou E (1998) Lofer cyclothems revisited (late Triassic, Northern Alps, Austria). Facies 38:207-228

Esteban M, Budai T, Juhász E, Lapointe Ph (2009) Alteration of Triassic carbonates in the Buda Mountains - a hydrothermal model, Central European Geology 52: 1-29

Fischer AG (1964) The Lofer Cyclothems of the Alpine Triassic. Kansas Geol Surv Bull 169:107-149

Fischer A. G. (1991) Orbital ciclicity in Mesozoic strata. - In: G. Einsele, W. Ricken, A.

Seilacher (eds.) Cycles and events in stratigraphy: 48-62, Springer-Verlag, Berlin

Frakes LA, Francis JL, Syktus JI (1992) Climate modes of the Phanerozoic. The history of the Earth's climate over the past 600 million years. Cambridge, UK Cambridge University Press $274 \mathrm{p}$

Frisia S (1994) Mechanisms of complete dolomitization in a carbonate shelf: Comparison between the Norian Dolomia Principale (Italy) and the Holocene of Abu Dhabi Sabkha. In: Purser B, Tucker M, Zenger D (eds) Dolomites IAS Spec Publ 21:55-74

Gattolin G, Preto N, Breda A, Franceschi M, Isotton M, Gianolla P (2015) Sequence srtratigraphy after the demise of a high-relief carbonate platform (Carnian of the Dolomites): sea-level and climate disentangled. Palaeogeogr Palaeoclimatol Palaeoecol, 423:1-17 
Gawlick HJ (2000) Paläogeographie der Ober-Trias Karbonatplattform in den Nördlichen Kalkalpen. Mitt Ges Geol Bergbaustud Österr 44:45-95.

Gianolla P, Roghi G, Ragazzi E. (2003) An Upper Tuvalian (Triassic) platform-basin system in the Julian Alps: the start-up of the Dolomia Principale (Southern Alps, Italy) Facies, 49:135-150

Góczán F, Oravecz-Scheffer A, Csillag G (1991) The stratigraphic characterization of the Cordevolian and Julian Formations of Csukréti Ravine, Balatoncsicsó. Földt Int Évi Jel 1989:241-323

Goldhammer RK, Dunn PA, Hardie LA (1990) Depositional cycles, composite sea-level changes, cycle stacking patterns, and the hierarchy of stratigraphic forcing: Examples from Alpine Triassic platform carbonates. Geol Soc Am Bull 102:535-562

Gregg JM, Bish DL, Kaczmarek SE, Machel HG (in press) Mineralogy, nucleation and groth of dolomite in the laboratory and sedimentary environment: A review. Sedimentology

Haas J (1982) Facies Analysis of the Cyclic Dachstein Limestone Formation (Upper Triassic) in the Bakony Mountains, Hungary. Facies 6:75-84

Haas J (1985) Senonian palaeogeographic relations of the Transdanubian Central Range. Annual Rep Hung Geol Surv 1983:95-109

Haas J (1988) Upper Triassic carbonate platform evolution in the Transdanubian MidMountains. Acta Geol Hung 31:299-312

Haas J (1991) A basic model for Lofer Cycles. In: Einsele G, Ricken W, Seilacher A (eds.): Cycles and Events in Stratigraphy. Springer-Verlag Berlin, Heidelberg, pp 722-732 Haas J (1994) Lofer cycles of the Upper Triassic Dachstein platform in the Transdanubian Mid-Mountains (Hungary). Spec Publ Int Ass Sedim 19 Oxford: 303-322 
Haas J (1995a) Upper Triassic platform carbonates in the Northern Bakony Mts. Földtani

Közlöny 125:27-64

Haas J (1995b) Upper Triassic platform carbonates of the northern Gerecse Mts. Földtani

Közlöny 125: 259-293

Haas J (2002) Origin and evolution of Late Triassic backplatform and intraplatform basins in the Transdanubian Range, Hungary. Geologica Carpathica 53:159-178

Haas J (2004) Characteristics of perididal facies and evidences for subaerial exposures in Dachstein-type cyclic platform carbonates in the Transdanubian Range, Hungary. Facies $50: 263-286$

Haas J (ed) (2012) Geology of Hungary. Springer Heidelberg, New York, Dordrecht, London. $244 \mathrm{p}$

Haas J, Budai T (1995) Upper Permian - Triassic facies zones in the Transdanubian Range. Riv Ital Paleontol Stratigr 101:249-266

Haas J, Budai T (1999) Triassic sequence stratigraphy of the Transdanubian Range, Hungary.

Geol Carpath 50/6:459-475

Haas J, Demény A (2002) Early dolomitisation of Late Triassic platform carbonates in the Transdanubian Range (Hungary). Sedimentary Geology 151:225-242

Haas J, Kovács S, Krystyn L, Lein R (1995) Significance of Late Permian-Triassic facies zones in terrane reconstructions in the Alpine-North Pannonian domain. Tectonophysics 242:19-40

Haas J, Budai T, Raucsik B (2012) Climatic controls on sedimentary environments in the Triassic of the Transdanubian Range (Western Hungary). Palaeogeogr Palaeoclimatol Palaeoecol 353-355: 31-44

Haas J, Budai T, Győri O, Kele S (2014) Multiphase partial and selective dolomitization of Carnian reef limestone (Transdanubian Range, Hungary) Sedimentology, 61:836-859 
Hips K, Haas J, Poros Zs, Kele S, Budai T (2015) Dolomitization of Triassic microbial mat deposits (Hungary): Origin of microcrystalline dolomite. Sedimentary Geology 318:113-129 Hoffman A, Gruszczynski M, Malkowski K (1991) On the interrelationship between temporal trends in $\delta^{13} \mathrm{C}, \delta^{18} \mathrm{O}, \delta^{34} \mathrm{~S}$ in the world oceans. J Geol 90:355-370

Iannace A. Frisia S 1994 Changing dolomitization styles from Norian to Rhaetian in the Southern Tethys realm. In: Purser B, Tucker M, Zenger D (eds) Dolomites IAS Spec Publ 21:75-89

Jadoul F, Berra F, Frisia S. (1992): Stratigraphic and paleogeographic evolution of a carbonate platform in an extensional tectonic regime: the example of the Dolomia Principale in Lombardy (Italy). Riv It Paleont Strat, 98:29-44

Jones GD, Xiao Y (2005) Dolomitization, anhydrite cementation, and porosity evolution in a reflux system: Insight from reactive transpost models. AAPG Bulletin 80:577-601 Juhász E, Korpás L, Balog A (1995) Two hundred million years of karst history, Dachstein Limestone, Hungary. Sedimentology 42: 473-489

Kent DV, Olsen PE (2000) Magnetic polarity stratigraphy and paleolatitude of the Triassic Jurassic Blomidon Formation in the Fundy basin (Canada). Implication for early Mesozoic tropical climate gradients. Earth and Planetary Science Letters 179:311-324

Korte Ch, Kozur H.W, Veizer J (2005) $\delta^{13} \mathrm{C}$ and $\delta^{18} \mathrm{O}$ values of Triassic brachiopods and carbonate rocks as proxies for coeval seawater and palaeotemperature. Palaeogeogr Palaeoclimatol Palaeoecol, 226:287-306.

Kovács S, Sudar M, Grădinaru E, Karamata S, Gawlick H-J, Haas J, Péró Cs,Gaetani M, Mello J, Polák M, Aljinovic D, Ogorelec B, Kollar-Jurkovsek T, Jurkovsek B, Buser S (2011) Triassic evolution of the tectonostratigraphic units in the Circum-Pannonian region. Jahrbuch der Geologischen Bundesanstalt, 151:199-280 
859

860

861

862

863

864

865

866

867

868

869

870

871

872

873

874

875

876

877

878

879

880

881

Kutzbach JE, Gallimore RG (1989) Pangean climates: Megamonsoons of the megacontinent. Journal of Geophysical Research 94:3341-3357

Land LS (1985) The origin of massive dolomite. Journal of Geological Education 33:112-125

Land LS (1986) Environments of limestone and dolomite diagenesis: some geochemical considerations. In: Bathurst RGC, Land LS (eds) Carbonate Depositional Environments. Part 1: Diagenesis Colorado Scool of Mines Quaterly vol 81. pp 26-41

Lohmann KC, Walker JCG (1989) The $\delta^{18} \mathrm{O}$ record of Phanerozoic abiotic marine calcite cements. Geophysical Research Letters 16:319-322

Machel HG (2004) Concepts and models of dolomitization: a critical reappraisal. In: Braithwaite CJR, Rizzi G, Darke G (eds): The Geometry and Petrogenesis of Dolomite Hydrocarbon Reservoirs, vol 235, Geol Soc (London) Spec Publ, pp 7-63

Mandl GW (2000) The Alpine sector of the Tethyan shelf - Examples of Triassic to Jurassic sedimentation and deformation from the Northern Calcareous Alps. Mitt Österr. Geol Ges 92 $61-77$

Marcoux J, Baud A, Ricou LE, Gaietani M, Krystyn L, Bellion Y, Guiraud R, Besse J, Gallet Y, Jaillard E, Moreau C, Theveniaut H (1993) Late Norian (215 to 212 Ma). In Dercourt J et al. (eds) Atlas of Tethys palaeoenvironmental maps. Paris, Gauthier-Villars, 35-53

Mazzullo SJ (2000) Organogenic dolomitization in peritidal to deep-sea sediments. Journ Sed Res 70:10-23

McCrea JM (1950) On the isotopic chemistry of carbonates and a paleotemperature scale. J Chem Phys 18:849-857

McKenzie JA (1981) Holocene dolomitization of calcium carbonatesediments from coastal sabkhas of Abu Dhabi, U.A.E.: a stable isotope study. J Geol 89:185-198 
882

883

884

885

886

887

888

889

890

891

892

893

894

895

896

897

898

899

900

901

902

903

904

905

McKenzie JA (1991) Controversies in modern geology: Evolution of geological theories in sedimentology, Earth history, and tectonics. In: Müller DW (eds) The Dolomite Problem: An outstanding Controversy, London Academic Press pp 37-54

Meister P, McKenzie JA, Bernasconi SM, Brack P (2013) Dolomite formation int he shallow seas of the Alpine Triassic. Sedimentology 60:270-291

Merino E, Canals A (2011) Self-accelerating dolomite-for-calcite replacement: Self-organized dynamics of burial dolomitization and associated mineralization. Am J Sci 311:573-607. doi: $10.2475 / 07.2011 .01$

Mullins HT, Wise MW, Land LS, Siegel DI, Masters PM, Hinchey EJ, Price KR (1985) Autigenic dolomite in Bahamian slope sediment. Geology 13:292-295

Ogorelec, B., Rothe, P. (1992): Mikrofacies, Diagenese und Geochemie des Dachsteinkalkes und Hauptdolomits in Süd-West-Slowenien. - Geologija, 35, 81-181, Ljubljana

Oravecz-Scheffer A (1987) Triassic foraminifers of the Transdanubian Central Range. Geol Hung ser Paleont 50, 331p Pálfy, J., Demény, A., Haas, J., Carter, E. S., Görög, Á., Halász, D., Oravecz-Scheffer, A., Hetényi, M., Márton, E., Orchard, M. J., Ozsvárt, P., Vető, I., and Zajzon, N. 2007. Triassic/Jurassic boundary events inferred from integrated stratigraphy of the Csővár section, Hungary. Palaeogeogr, Palaeoclimat, Palaeoecol 244:11-33

Poros Zs, Machel H, Mindszenty A, Molnár F (2013) Cryogenic powderization of Triassic dolostones in the Buda Hills, Hungary, Int J Earth Sci 102: 1513-1539

Preto N, Kustatscher E, Wignall $\mathrm{PB}(2010)$, Triassic climates-state of the art and perspectives, Palaeogeogr Palaeocl Palaeoec 290:1-10

Roghi G, Gianolla P, Minarelli L, Pilati C, Preto N (2010) Palynological correlation of Carnian humid pulses throughout western Tethys. Palaeogeogr. Palaeocl. Palaeoec., 290: 89-106 
Rostási Á, B. Raucsik B Varga V (2011) Palaeoenvironmental controls on the clay mineralogy of Carnian sections from the Transdanubian Range (Hungary). Palaeogeogr Palaeocl Palaeoec 300: 101-112

Sander B (1936) Beiträge zur Kenntnis der Anlagerungsgefüge. Mineral und Petrogr Mitteil 48:27-139

Satterley AK (1996) Cyclic carbonate sedimentation in the Upper Triassic Dachstein Limestone, Austria: the role of patterns of sediment supply and tectonics in a platform-reefbasin system. J Sediment Res 66(2):307-323

Satterley AK, Brandner R (1995) The genesis of Lofer cycles of the Dachstein Limestone, Northern Calcareous Alps, Austria. Geol Rundsch 84:287-292

Simms MJ. Ruffell AH (1989) Synchroneity of climatic change and extinctions in the Late Triassic. Geology 17: 265-268

Sánchez-Román M, Vasconcelos C, Schmid Th, Dittrich M, McKenzie JA, Zenobi R, Rivadeneyra MA (2008) Aerobic microbial dolomite at the nanometer scale: implications for the geologic record. Geology 36:879-882

Spadafora A, Perri E, McKenzie JA, Vasconcelos C (2010) Microbial biomineralization processes forming modern Ca:Mg carbonate stromatolites. Sedimentology 57:2740

Spötl C, Pitman JK (1998) Saddle (baroque dolomite) in carbonates and sandstones: a reappraisal of a burial diagenetic concept. vol 26, IAS Spec Publ, pp 437-460

Spötl C, Vennemann TW (2003) Continuous-flow isotope ratio mass spectrometric analysis of carbonate minerals. Rapid Commun Mass Spectrom 17:1004-1006.

Strasser A (1991) Lagoonal-peritidal sequences in carbonate environments: autocyclic and allocyclic processes. In: Cycles and Events in Stratigraphy G. Einsele, W. Ricken, A. Seilacher (eds), 709-721, Berlin (Springer) 
Vasconcelos C, McKenzie JA (1997) Microbial mediationof modern dolomite precipitation and diagenesis under anoxic conditions, Lagoa Vermelha, Rio de Janero, Brazil. J Sed Res $67: 378-390$

Végh-Neubrandt E (1982) Triassische Megalodontaceae. Budapest, Akadémia Kiadó, 526 p.

Veizer J (1983) Trace elements and isotopes in sedimentary carbonates. In Reeder RJ (ed)

Carbonates: Mineralogy and Chemistry Rev Mineral vol 11 pp 265-299

Warren J (2000) Dolomite: occurrence, evolution and economically important associations. Earth Science Reviews 52:1-81

Wright DT (2000) Benthic microbial communities and dolomite formation in marine and lacustrine environments - new dolomite model. In: Glenn CR, Pevot-Lucas L, Lucas J (eds) Marine Authigenesis: From Global to Microbial. SEPM Spec Publ 66, pp 7-20

Wright DT, Wacey D (2005) Precipitation of dolomite using sulphate-reducicing bacteria from the Coorong Region, South Australia: significance and implication. Sedimentology 52:987-1008

\section{Figure captions}

Fig. 1 a Position of the studied area in the Transdanubian Range (TR). Abbreviations: A: Austria, SK: Slovakia, U: Ukraine, RO: Romania, SRB: Serbia, CR: Croatia, SLO: Slovenia. b Extension of the Triassic formations in the Transdanubian Range and position of the studied sections. 1 Disznó Hill Quarry; 2 Benedek Hill, Veszprém; 3 Aranyosvölgy Quarry, Veszprém; 4 Horogvölgy exposure; 5 Csákánykő Quarry; 6 Epöl Quarry; 7 Core Ugod Ut-8; 8 Core Porva Po-89; Csb Csővár blocks

Fig. 2 Stratigraphic scheme for the Upper Triassic of the Transdanubian Range (after Haas and Budai 1999, modified) showing the stratigraphic setting of the studied sections. 1 Disznó Hill Quarry; 2 Benedek Hill, Veszprém; 3 Aranyosvölgy Quarry, Veszprém; 4 Horogvölgy 
exposure; 5 Csákánykő Quarry; 6 Epöl Quarry; 7 Core Ugod Ut-8; 8 Core Porva Po-89. Abbreviations: Fm - Formation; Mb - Member; MF - Mátyáshegy Fm; RD - Rezi Dolomite; RH - Remetehegy Mb; SD - Sédvölgy Dolomite; SH - Sándorhegy Fm

Fig. 3 Petrographic features of the Gémhegy Dolomite in the Disznó Hill Quarry. a Alternation of Lf C and Lf B beds in the lower part of the studied interval. The label with letters marks the positions of photos b-e. b Lf B stromatolite bed (D-98). c Fenestral laminated clotted micrite fabric of Lf B (D-98). $\mathbf{d}$ and e The micritic grains and matrix show bright red luminescence in this fabric preserving replacive dolomite. The small pores are filled with finely crystalline, cloudy dolomite, showing mottled CL (d1). A larger pore (centre) is lined with a similar, medium crystalline, planar-s dolomite (d1) and is overgrown by a dull zoned dolomite phase (d2). A bright red phase (blue arrows) marks the boundary between the dull and a somewhat brighter red zoned dolomite phase (d3) crosscutting earlier cements and penetrating into the replacive dolomite. Note the selective dissolution of some of the younger zones in $\mathrm{d} 3$ (open porosity is black) (D-98). $\mathbf{f}$ and $\mathbf{g}$ The core of this planar dolomite cement crystal is mottled (d1), overgrown by a dull, limpid zone (d2). Blue arrow marks a very thin bright zone, suggesting dissolution, preceding the precipitation of $\mathrm{d} 3$ (D101). h Pedogenically altered bioclastic wackestone. The probably root-related elongated pores are lined by finely laminated micrite and occluded by finely to medium crystalline planar-c dolomite (D-101).

Fig. 4 Petrographic features of the Gémhegy Dolomite at Benedek Hill. a Massive dolomite in the lower part and thin to medium-bedded dolomite in the upper part of the section at the western side of Benedek Hill. b Fabric destructive finely to medium sized planar-s dolomite with cloudy cores and limpid rims (D-125). c Relic peloidal texture with a gastropod mould (D-126). d Pores of this fabric destructive, replacive dolomite are partly occluded by medium crystalline, planar dolomite. The cloudy cores with mottled CL (d1) are followed by a dull 
zoned dolomite phase (d2). The final cement phase is a bright red zoned dolomite (d3). P: open pore (D-126). f Ghosts of dasycladalean algae and mollusc fragments (D-27A). g Ghosts of unidentifiable grains and micrite peloids (D-27B).

Fig. 5 Petrographic features of the Födolomit Formation in the Aranyosvölgy Quarry. a Lithologic log of the exposed section. Positions of the displayed photos are marked beside the $\log . \mathbf{b}$ and $\mathbf{c}$ mudstone-wackestone texture with peloids and bioclasts. The shrinkage cracks and vugs are filled by very finely to finely crystalline dolomite (D-29B). d and e Intergranular pores are filled by finely crystalline dolomite with mottled CL (d1). A larger pore (centre) is lined with medium crystalline, cloudy, planar-s cement with a similar mottled appearance (d1), which is overgrown by a dull zoned dolomite cement (d2). The final cement phase is a somewhat brighter, zoned dolomite (d3) (D-29A). f Laminated texture. Laminae of clotted micritic fabric alternate with fenestral pore-rich laminae (D-127). g Intraclastic, peloidal lamina; the larger pores are filled by medium crystalline planar-c dolomite (D-127). h Intraclasts and fragments of clotted micrite; the pore network is filled by medium-coarsely crystalline dolomite (D-127). i Peloidal grainstone; the intergranular pores are occluded by very finely crystalline dolomite (D-128).

Fig. 6 Petrographic features of the Födolomit Formation in the Horogvölgy exposure. a Typical undulating laminated clotted micritic fabric of Lf B (D-103). b Spherical objects (microproblematica) with micritic contours (yellow arrow) in clotted micrite (D-103). c Replacive dolomite with clotted micritic fabric and planar dolomite cement. Box indicates the location of the pore filling shown in $\mathrm{d}$. $\mathbf{d}$ The pores are lined by a thin dolomite crust of very dull CL (d1) succeeded by a non-luminescent zone (d2), which is followed by a limpid, planar dolomite phase showing bright zonation (d3). P: open pore (D-103). e and f Fabric preserving replacive dolomite of bioclastic grainstone texture. Pores are lined by finely to medium crystalline planar dolomite cement. The medium crystalline dolomite cements exhibit a 
peculiar zonation: a thick dull zone (d1) is followed by several thin zones of bright, dull and non-luminescent zones with gradual or sharp transitions (d2). The remaining pore space is occluded by non-luminescent-bright orange, irregularly zoned calcite (c) (D-102).

Fig. 7 Petrographic features of the Fődolomit Formation in the Csákánykő Quarry. a The exposed section of the upper part of the Födolomit Formation is made up predominantly of $\mathrm{Lf}$ B stromatolite beds (D-90, 91, 93, 95) with thin non-laminated Lf C interbeds (D-90, 94). b Stromatolite showing undulating laminated, and locally domical structure with fenestral pores (D-91). c Alternation of laminae of dense micrite, clotted micrite and finely crystalline sparite formed via merging of small fenestrae. Stained thin-section. (D-91). d Millimetre-sized domical structure in stromatolite. Stained thin-section. (D-90) e Replacive dolomite with stromatolite texture. The larger pores are lined by zoned planar-c dolomite followed by a thick zone of non-luminescent, drusy calcite. In the centre of the pore the calcite shows bright orange zonation (D-93b) f Very finely crystalline dolomite with peloids and micritic intraclasts at the basal part of an Lf C bed (D-92) g Well-preserved sedimentary fabric abundant in peloids, and micritic intraclasts (D-96)

Fig. 8 Petrographic features of the Fenyőfö Member in the Epöl Quarry. Stained thin-sections. a Lithologic log of the exposed section. Positions of the displayed photos are marked beside the log. b Dolomicrite-microsparite showing mm-scale lamination - laminar dolocrete (Lf A) c Cm-sized dolomicrite clasts in a dolocrete layer. d Clotted micrite fabric; filament structure of microbial mat is preserved locally e Dense clotted micrite of brownish colour, fenestral laminated structures and sheet-cracks with very finely crystalline dolomite internal sediment on the bottom of the pore while its upper part is occluded by blocky calcite. $\mathbf{f}$ Echinoderm fragment in finely crystalline dolomite matrix. g Scattered euhedral (planar-p) dolomite crystals in undolomitized micrite matrix. h Partially dolomitized calcimicrite; the vuggy pores 
are lined by finely crystalline dolomite and filled with blocky calcite. i Megalodont mould filled by coarsely crystalline planar-c dolomite with dedolomite zones and blocky calcite

Fig. 9 Cyclic alternation of the lithofacies types, and rock composition of the Fenyöfö Member in the core Ugod-8 (Ut-8), and interpretation of the depositional environments. Position of one of the photos displayed in Fig. 12 is marked beside the log.

Fig. 10 Cyclic alternation of the lithofacies types, and rock composition of the Fenyöfö Member and the lower part of the Dachstein Limestone ss. in the core Porva-89 (Po-89) and interpretation of the depositional environments. Positions of photos displayed in Fig. 11 and Fig. 12 are marked beside the $\log$.

Fig. 11 Petrographic features of the Fenyöfö Member in the core Ut-8 and Po-89. a and b Clotted micrite with fenestral pores which are lined by limpid dolomite rhombs and occluded by blocky calcite; Stained thin-sections. a Po-89 $465 \mathrm{~m}$; b Po-89 468 m. c Scattered tiny dolomite rhombs (planar-p) appear mostly in peloids, and micritized parts of bioclasts. Po-89 467 m. d Irregular patches of finely crystalline planar-s dolomite in recrystallized limestone. Stained thin-section. Ut-8 $23 \mathrm{~m}$.

Fig. 12 Petrographic features of the lower part of the Dachstein Limestone s.s. in the core Po89. Stained thin-sections. a Dolomite intraclasts in non-dolomitized peloidal, bioclastic wackestone (Lf C); $408 \mathrm{~m}$. b clotted dolomicrite fabric with fenestral pores fringed by limpid dolomite rhombs and filed by blocky calcite; $412 \mathrm{~m}$. c Geopetal pore-filling; dolomite and calcite silt and mud internal sediment occur at the basal part of the pore and blocky calcite occludes the remnant pore space; $411 \mathrm{~m}$. d Geopetal pore-filling; ostracods occur in the internal sediment; $405 \mathrm{~m}$.

Fig. 13 Carbon - oxygen isotopic compositions of Upper Triassic platform carbonate units in the Transdanubian Range. The measured values of the present study are marked by symbols referring to the sampled lithostratigraphic units and the texture preservation of the samples. 
1054 The outlined fields show the ranges of those values reported in previous papers. 1055 Abbreviations: DS: Dachstein Limestone Formation; upper part, Rhaetian (Haas 1995b); FD B: Fődolomit Formation, Norian - tidal-flat dolomite (Balog et al. 1999); FD C: Fődolomit

1057 Formation, Norian - subtidal dolomite (Balog et al. 1999); FF: Fenyőfö Member of the Dachstein Formation, Upper Norian - peritidal dolomite (Haas and Demény 2002); *Upper Triassic marine calcite (Korte et al. 2005)

Fig. 14 Palaeogeographic models showing the changes of the environmental conditions which controlled the early dolomitization in the Transdanubian Range from the late Carnian to the end of Triassic.

Table 1 Summary table of the petrographic features

Abbreviations: Lf B: B lithofacies-type; Lf C: Lithofacies-type; fs: fabric selective; nfs: nonfabric selective; VF-F-M: very finely - finely - medium crystalline; M-C: medium - coarsely crystalline; BC: blocky calcite; DD: dedolomite; cm: clotted micrite; F-F p-s: very fine to fine crystalline, planar-s; bk-gh: bioclast ghosts

Table 2 Results of the stable isotope analyses

Abbreviations: $\mathrm{cm}$ - clotted micrite; VF - very finely crystalline; $\mathrm{F}$ - finely crystalline; $\mathrm{M}$ medium crystalline; C - coarsely crystalline; GFP - good fabric preservation; MFP - medium fabric preservation; PFP - poor fabric preservation; FD - fabric destructive; CEM - cement; GH - Gémhegy Dolomite; DS - Dachstein Formation 


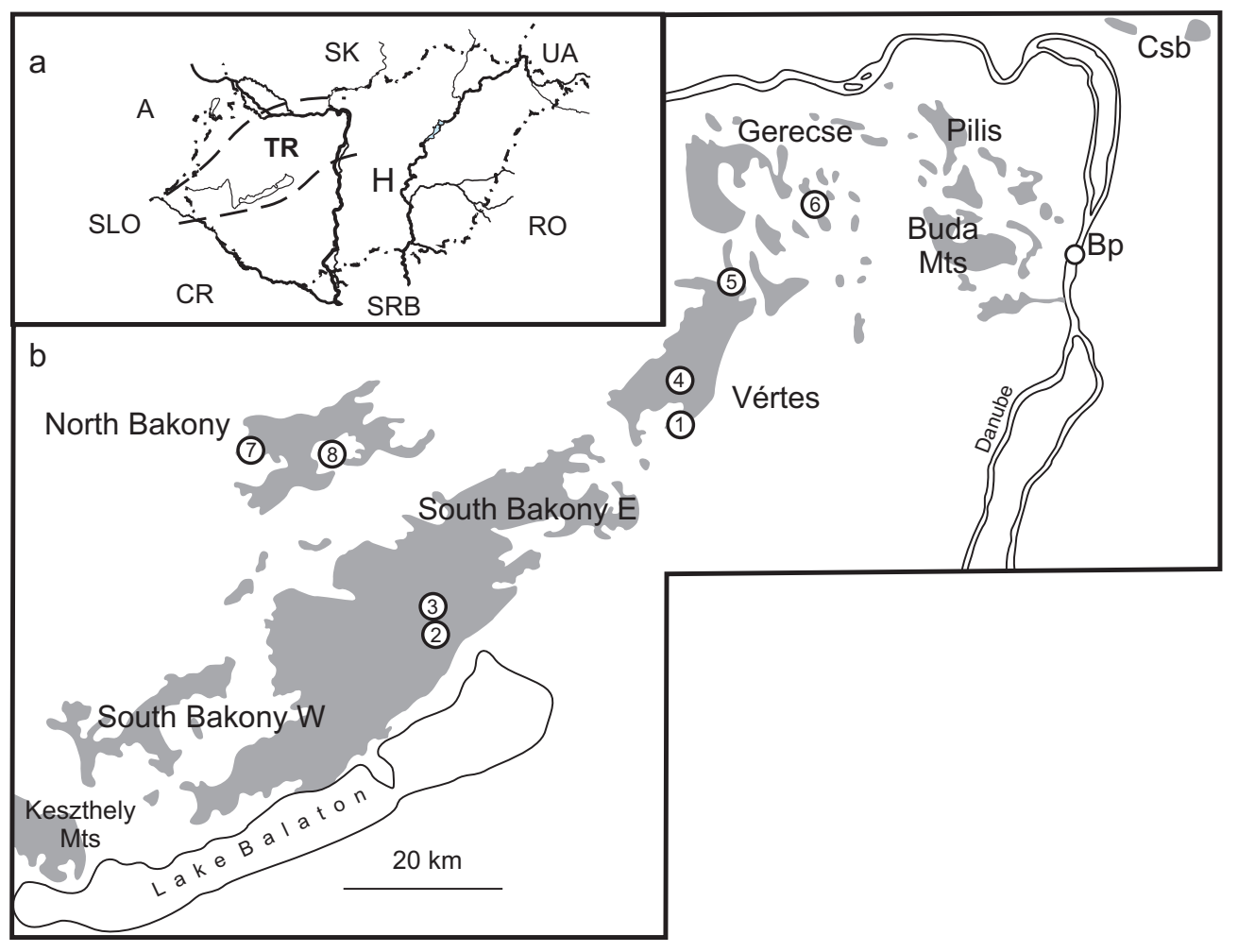


SW

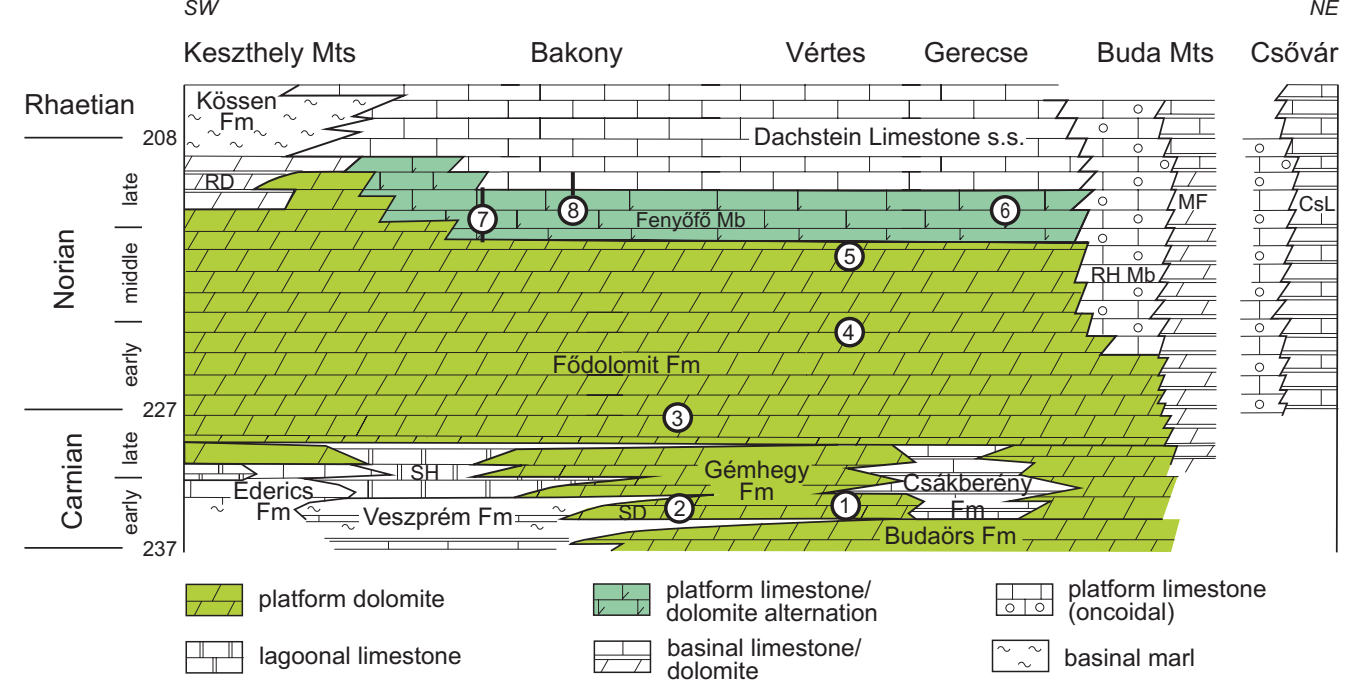



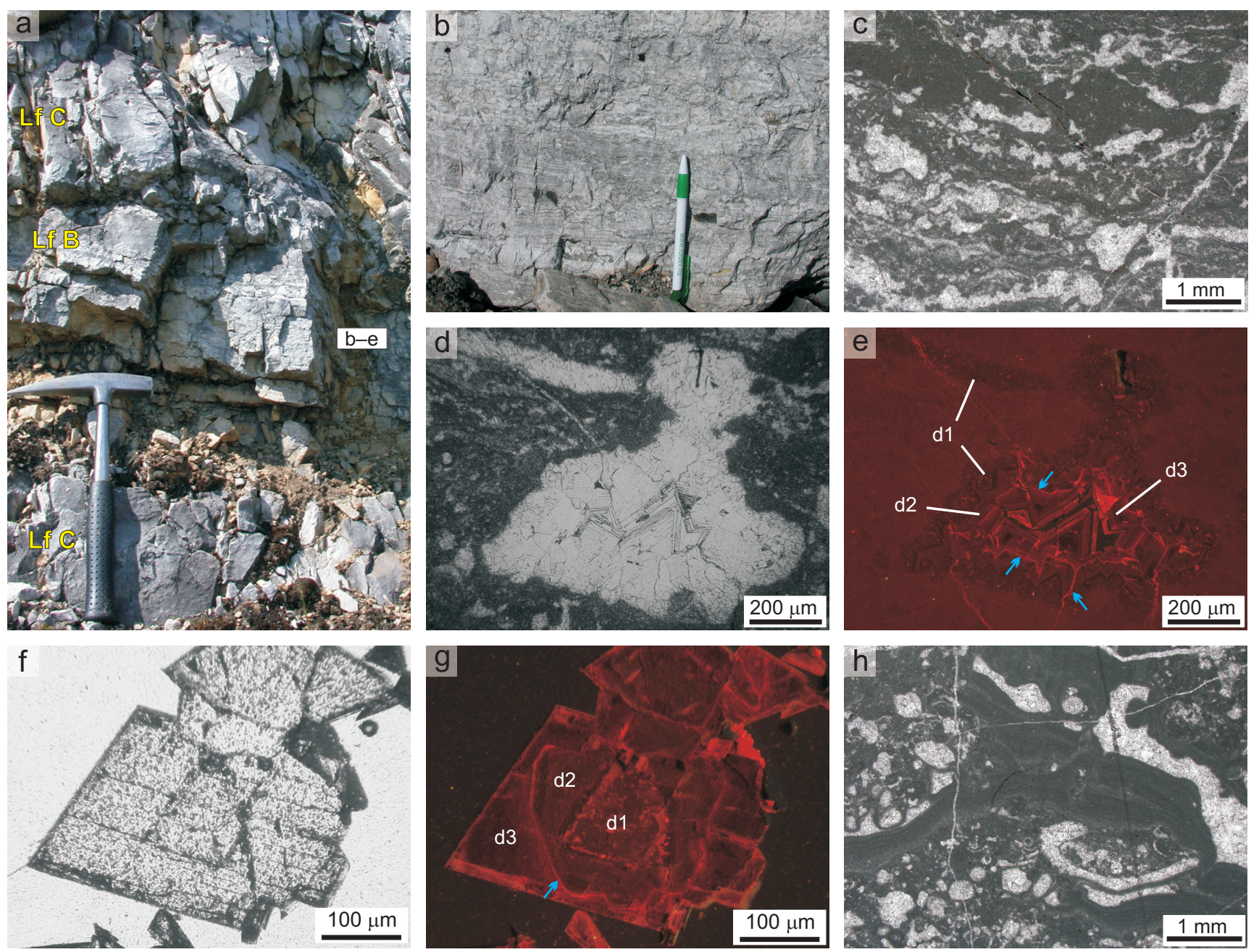

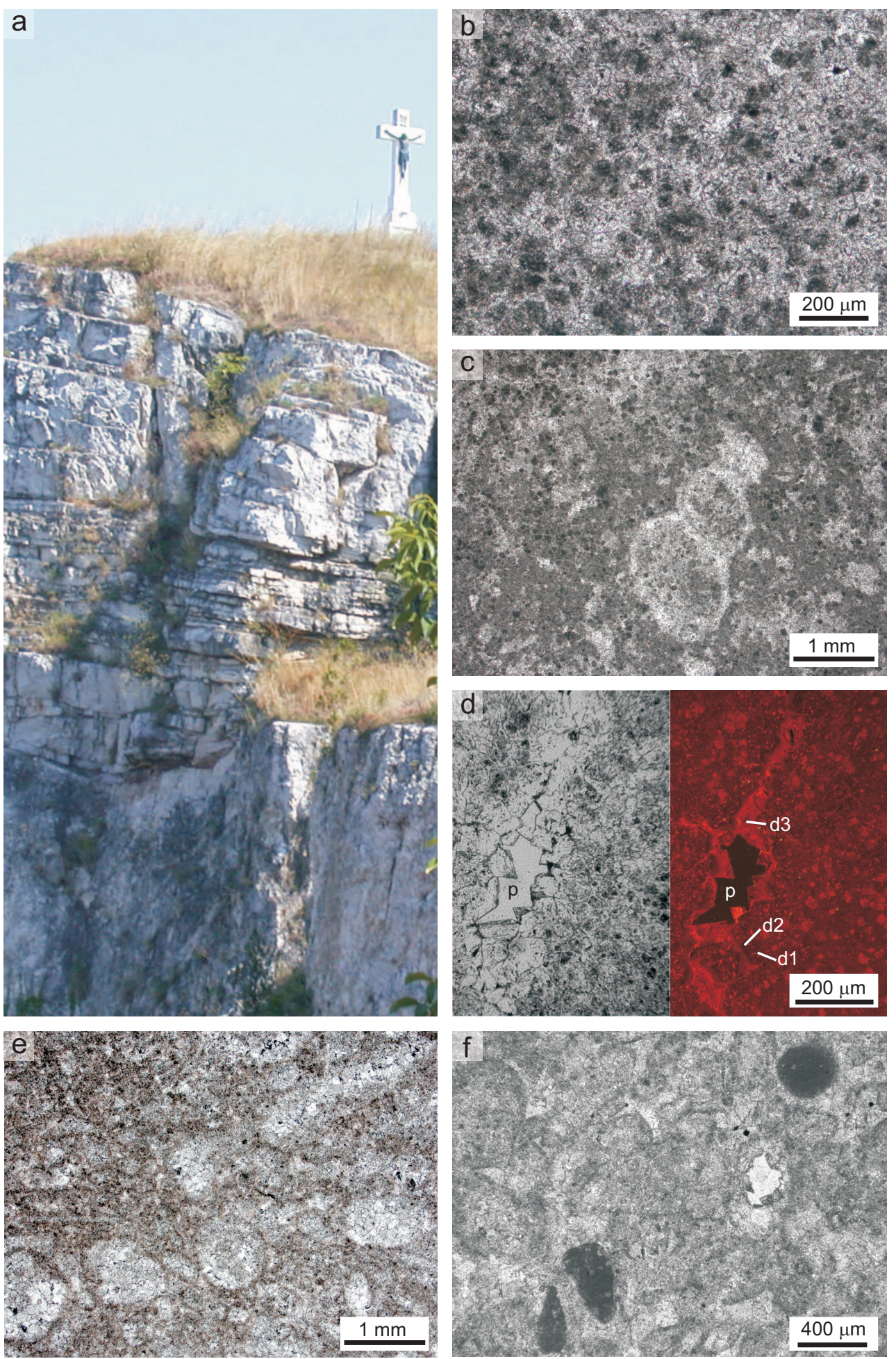
a

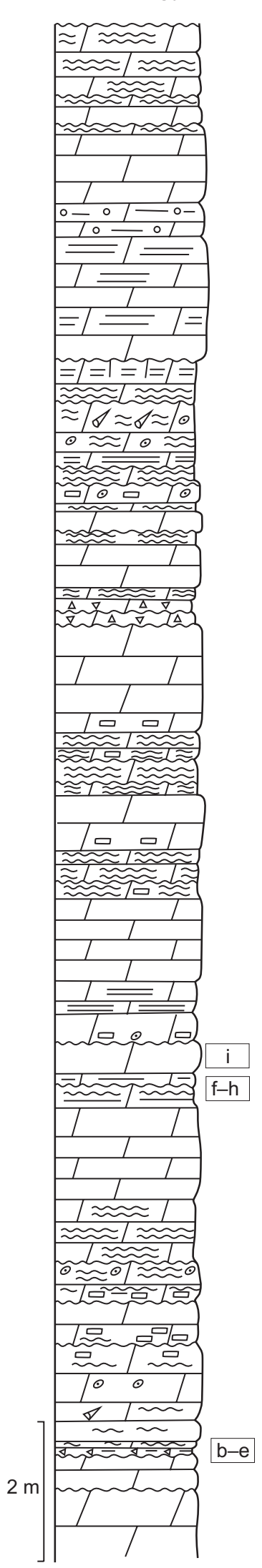

\section{Lf}

$\mid$\begin{tabular}{c|}
$B$ \\
$B C$ \\
$B C$ \\
\hline$C$ \\
\hline$B$ \\
$C C$ \\
\hline$B-C$ \\
\hline$B-C$
\end{tabular}
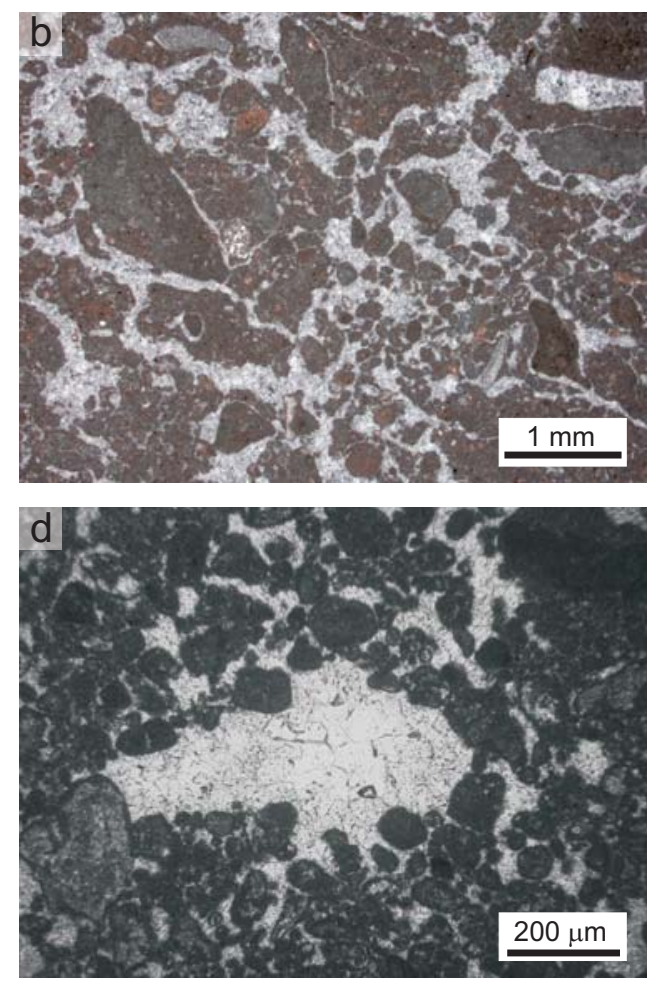

C

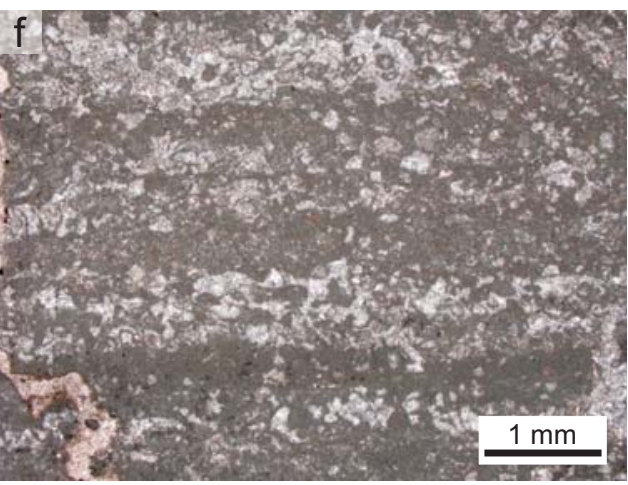

B-C

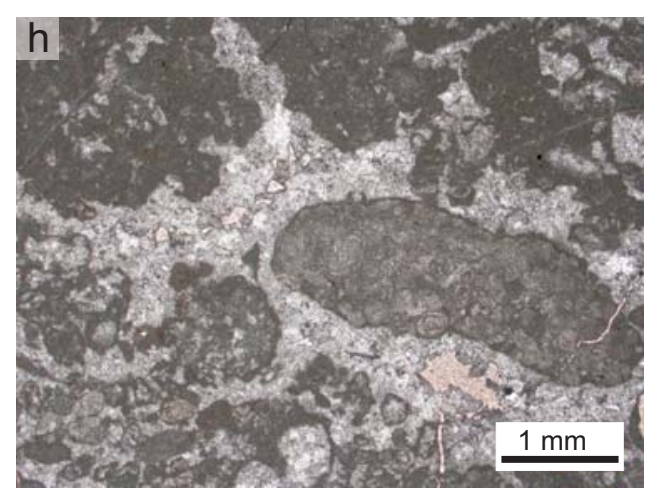

$\stackrel{\mathrm{B}}{\mathrm{C}}$

B-C

A
B dolomite clayey dolomite $\odot \odot \odot$

(B) dolomite

C 口ロ flat pebbles
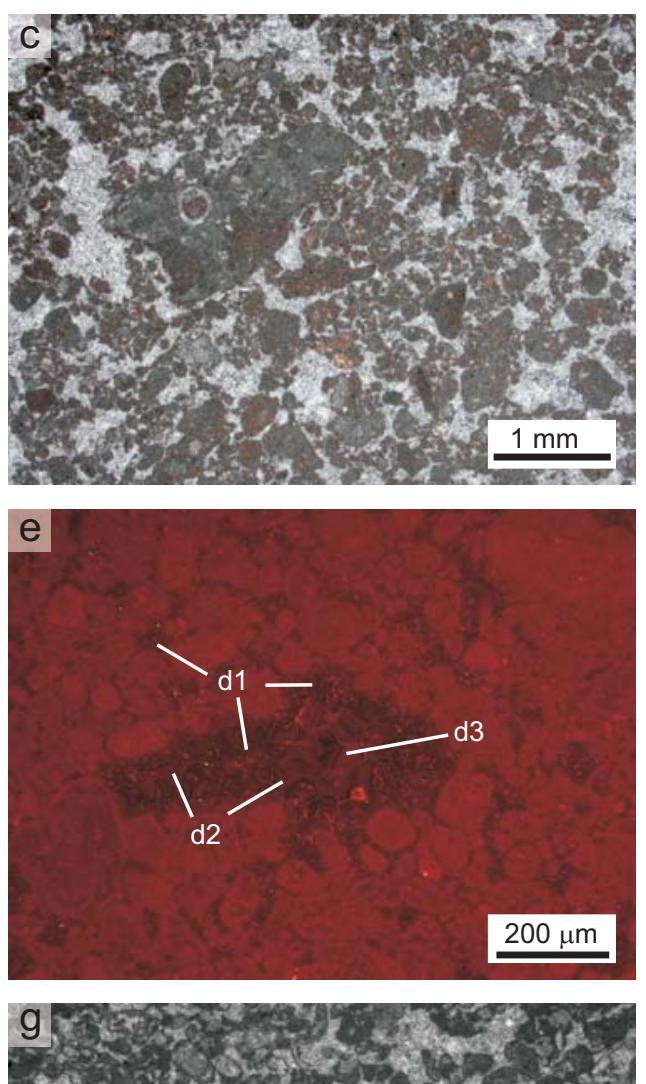

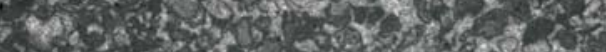

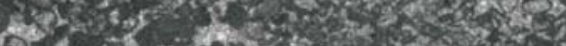
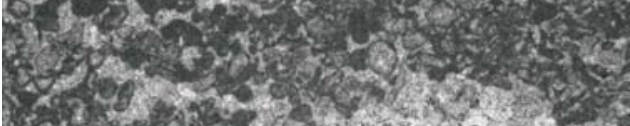

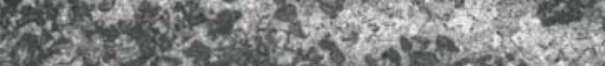

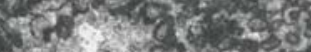

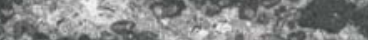
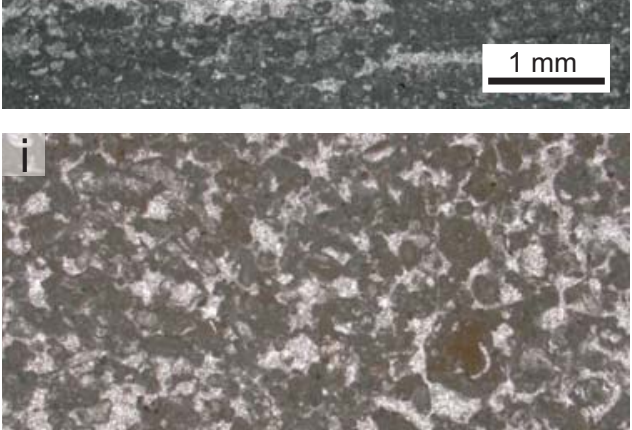

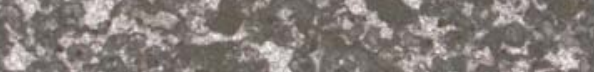

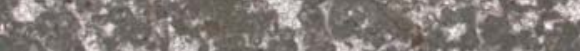
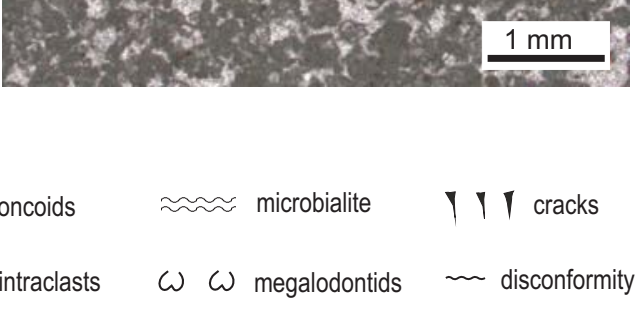

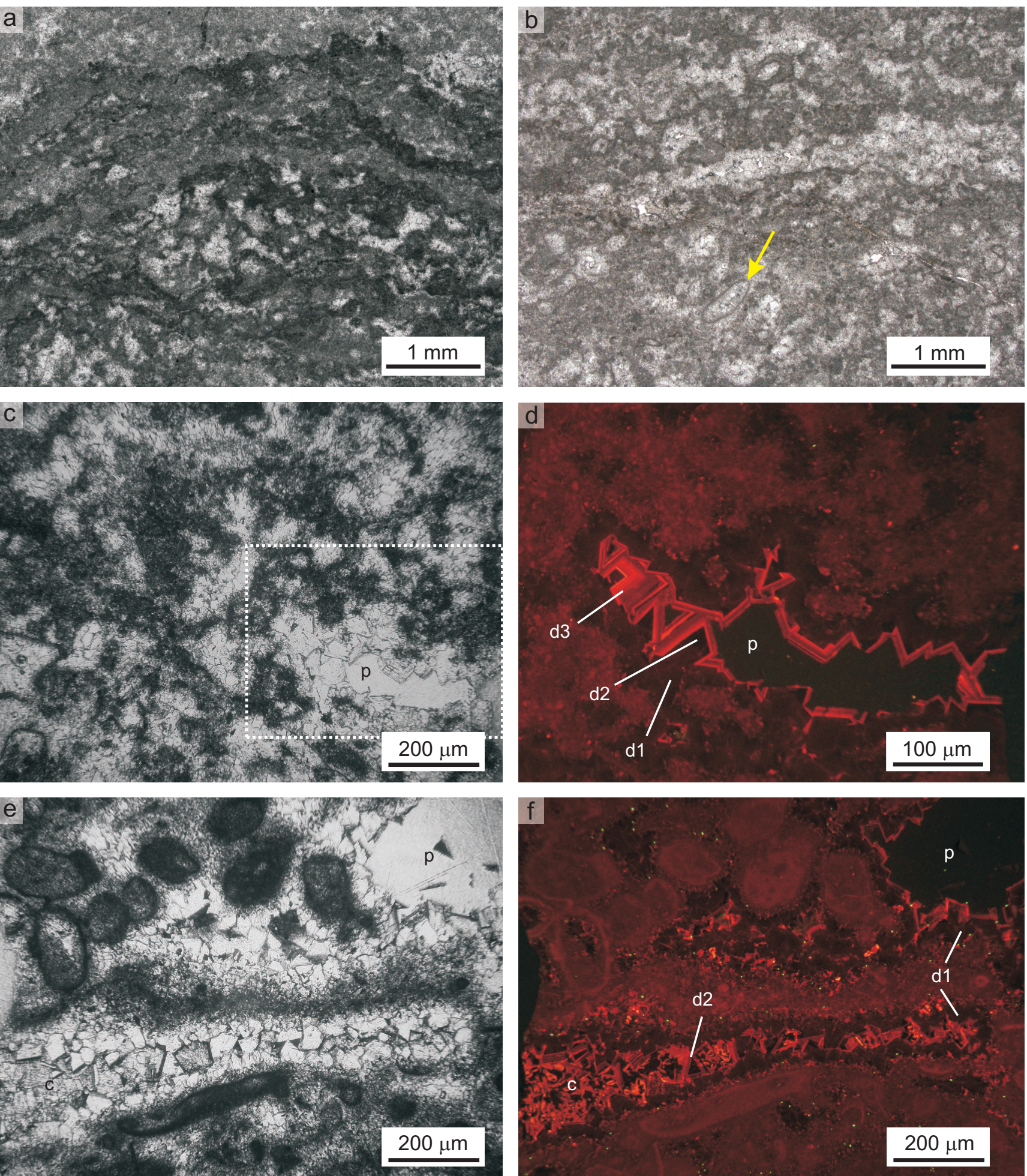

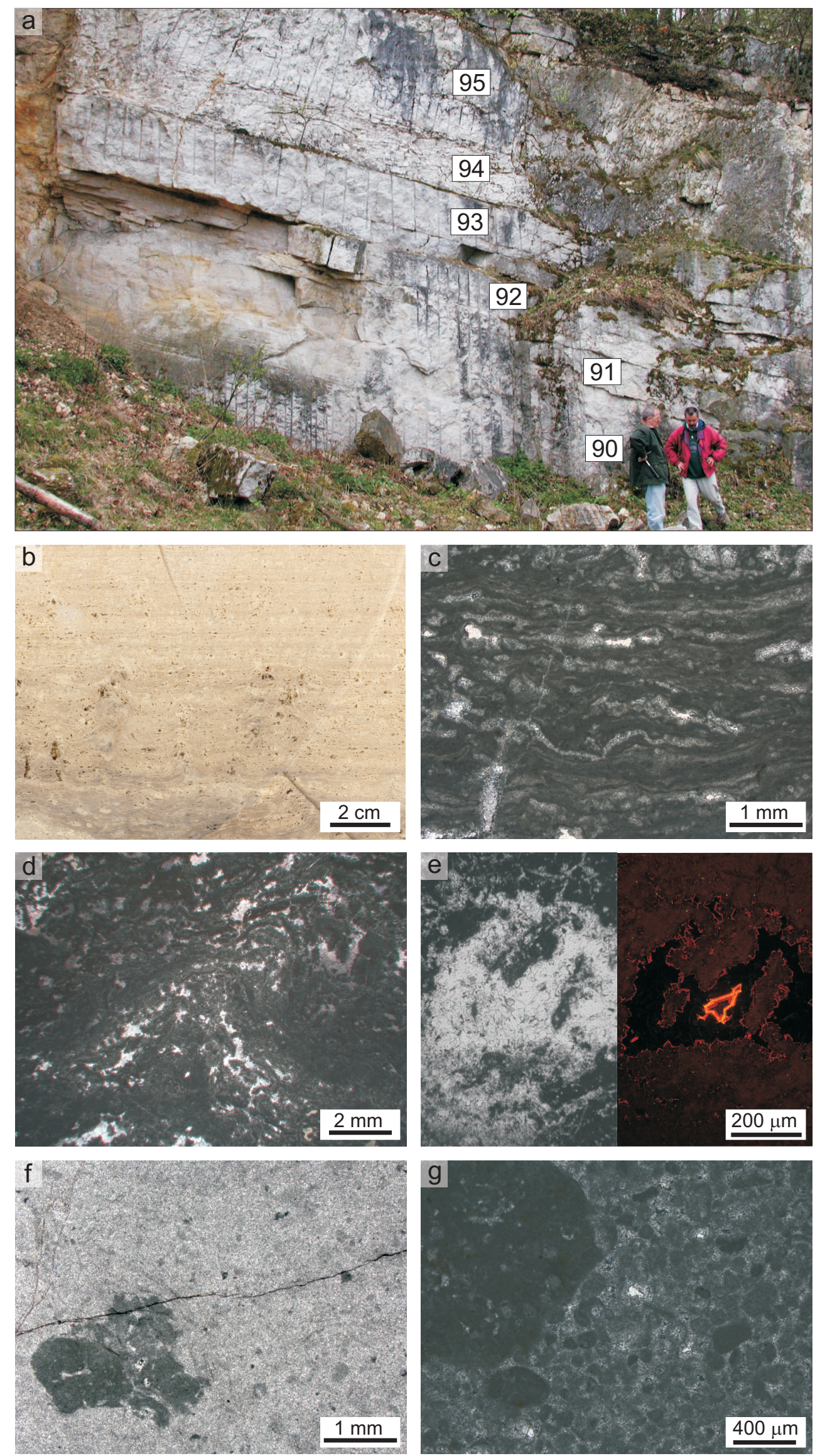


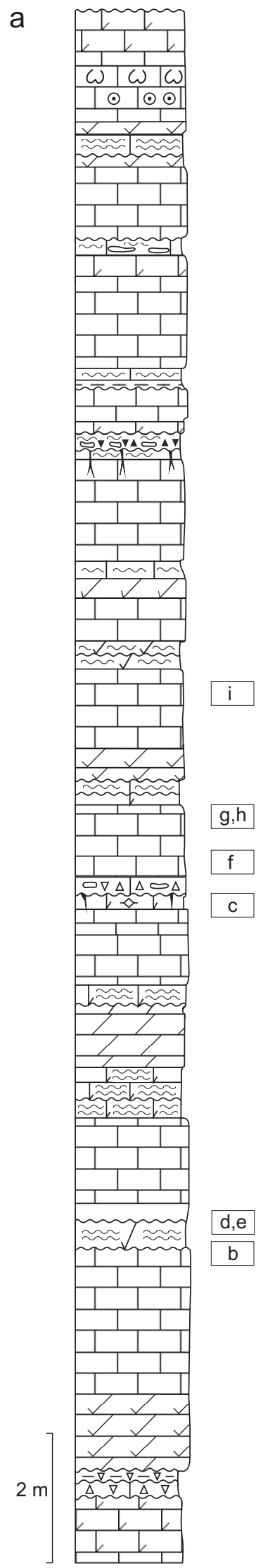

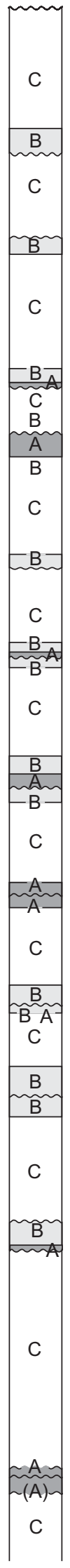
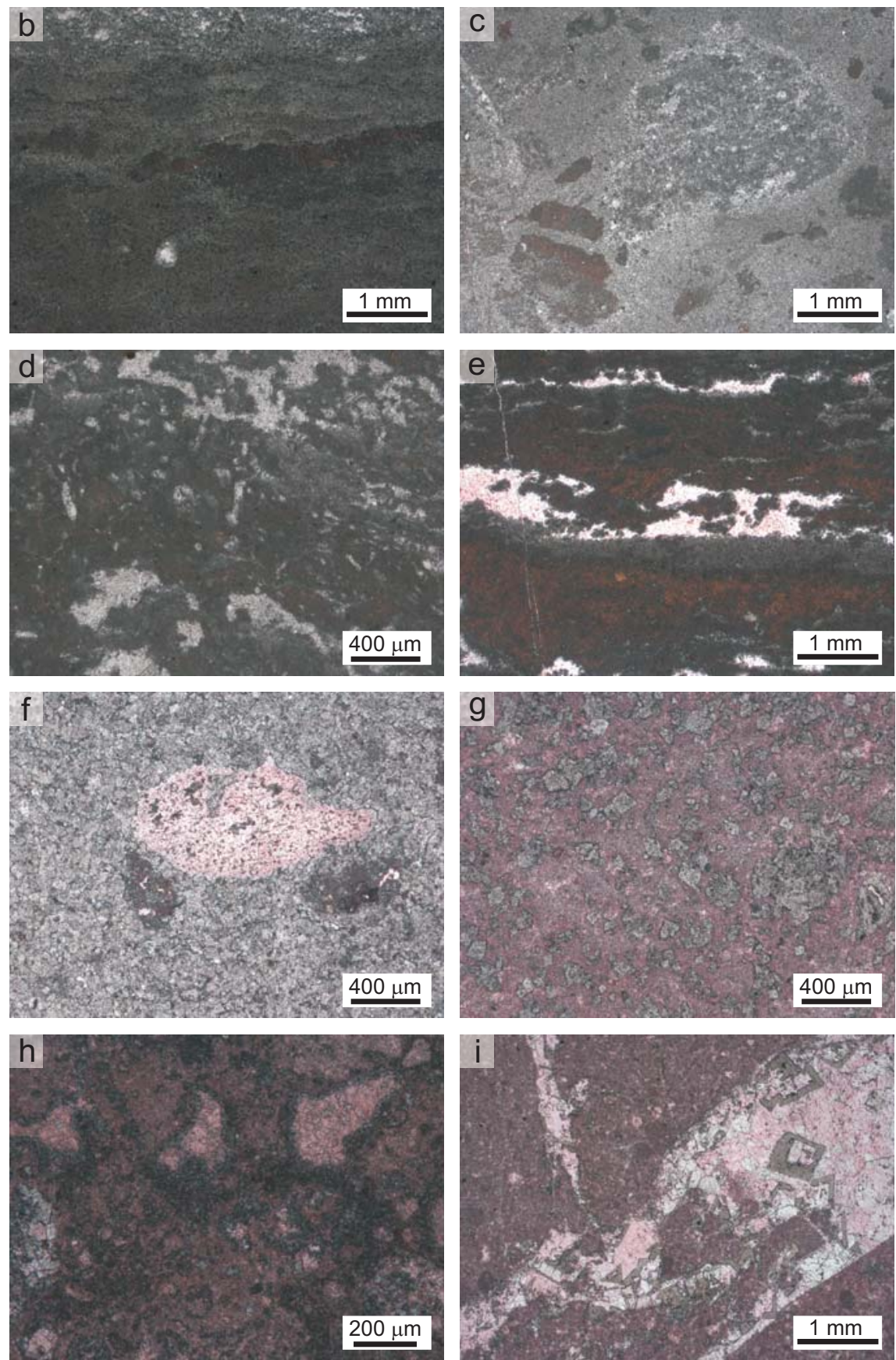

$\square$ limestone \& 8 dolomite

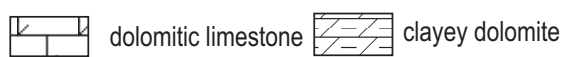

$\odot \odot \odot$ oncoids

$\approx \approx$ microbialite

$\boldsymbol{\nabla} \boldsymbol{\nabla}$ black pebbles

$\checkmark$ calcitic dolomite

$\square \square$ flat pebbles

$\nabla \Delta \nabla$ intraclasts

$\circlearrowleft \circlearrowleft$ plasticlasts

$m$ disconformity $\quad 1$ cracks $\omega \omega$ megalodontids 


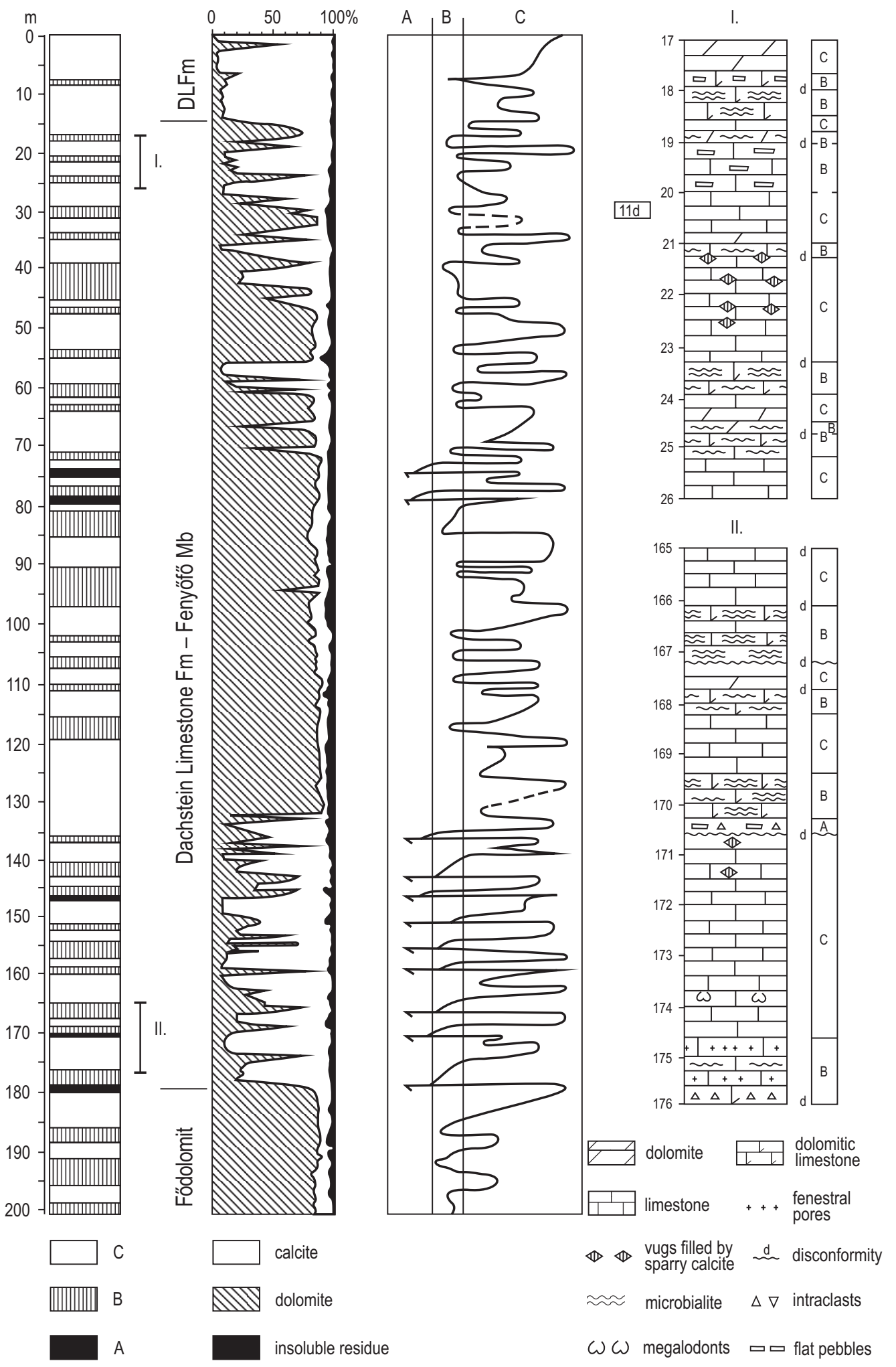


Lf

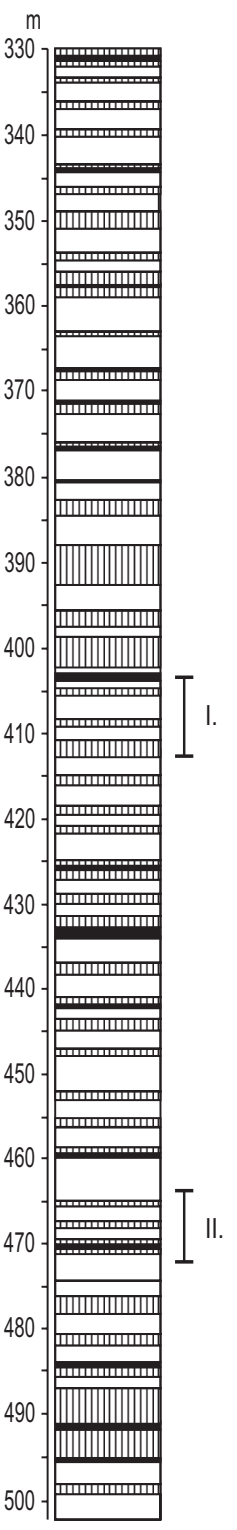

$\square$ C

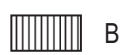

Composition

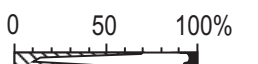

Doms

5

5

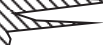

5

D.<smiles>c1ccncc1</smiles>

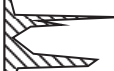

-

$\infty$

은

.

든

옹

$\stackrel{\text { Е }}{\Xi}$

Nए

5

.气

$\frac{.}{\frac{1}{\omega}}$

क्ष

๑ั

1.50

115

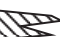

10

$1+$

5

ins

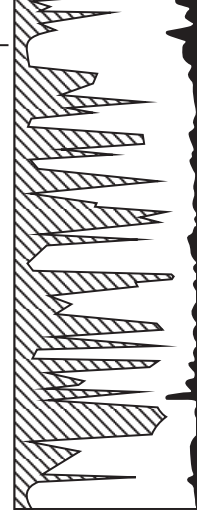

$\square$ calcite

MIN dolomite

insoluble residue
Palaeoenvironment

Lithology

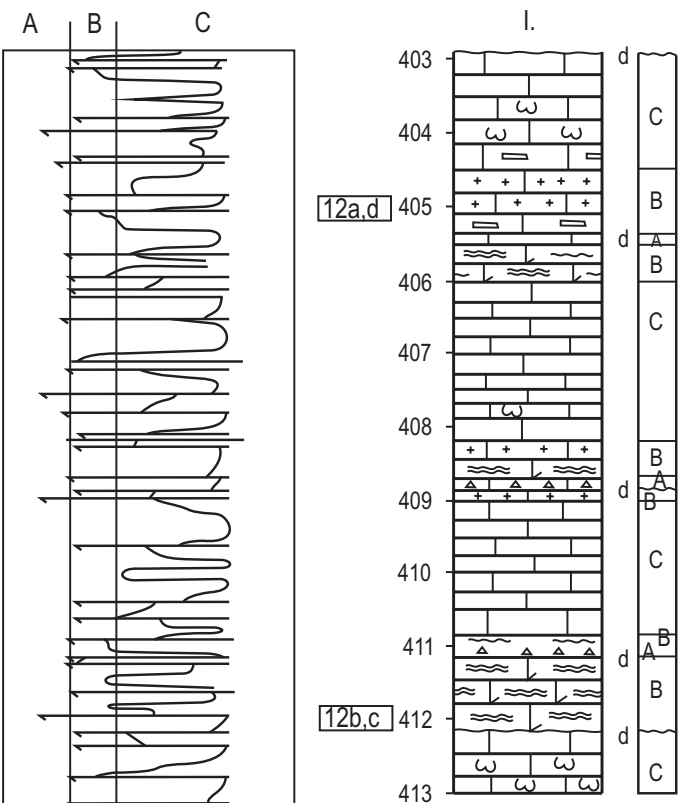

II.

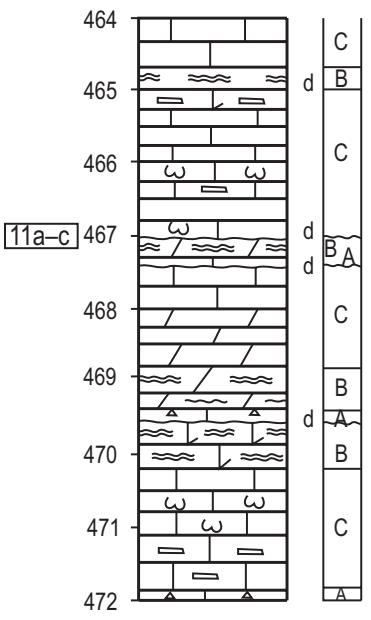

$\sum$ dolomite $I^{2}$ dolomitic $\square$ limestone $\square$ limestone

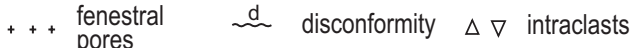

$\omega \omega$ megalodonts ロロ flat pebbles 

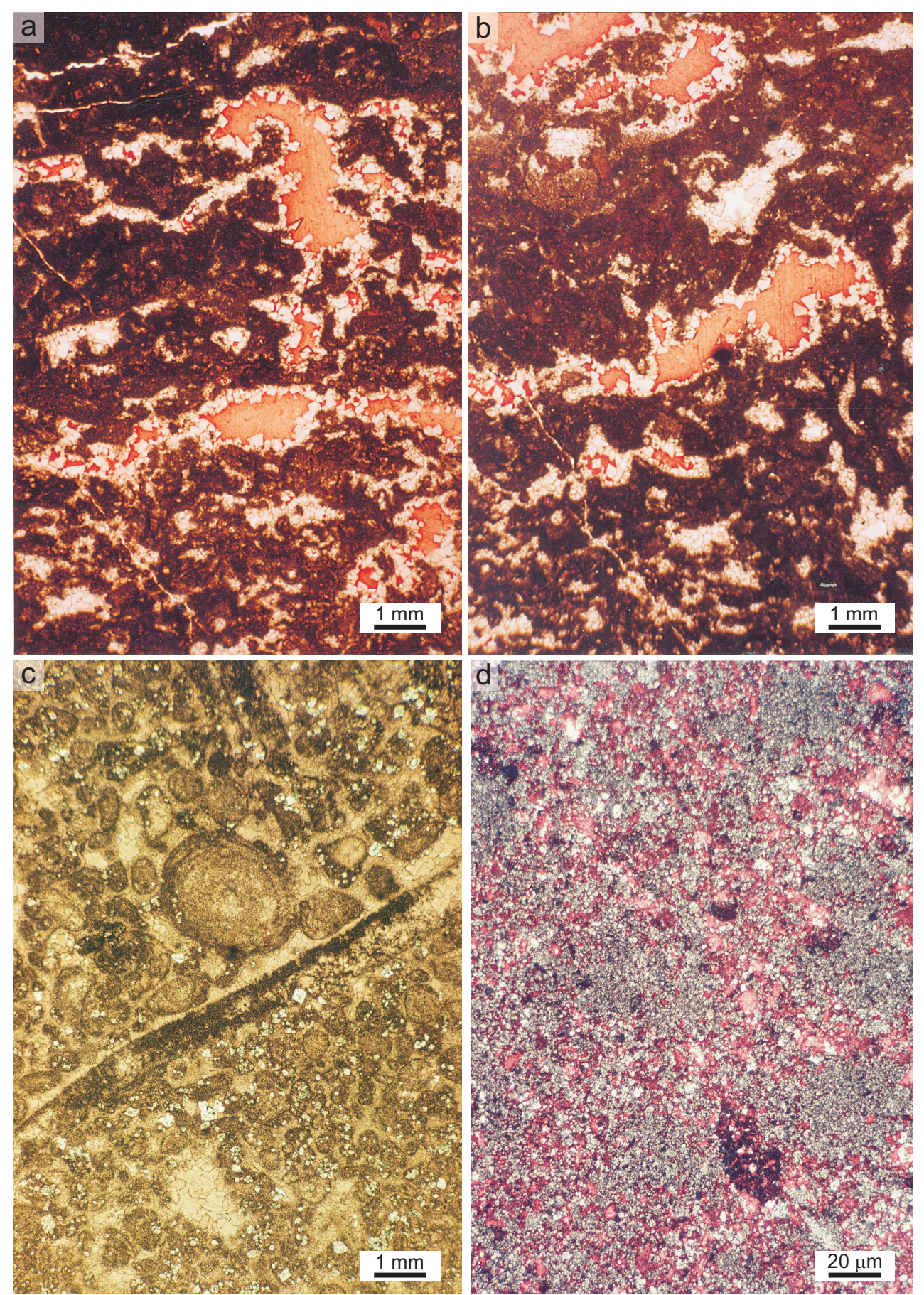


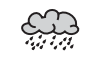

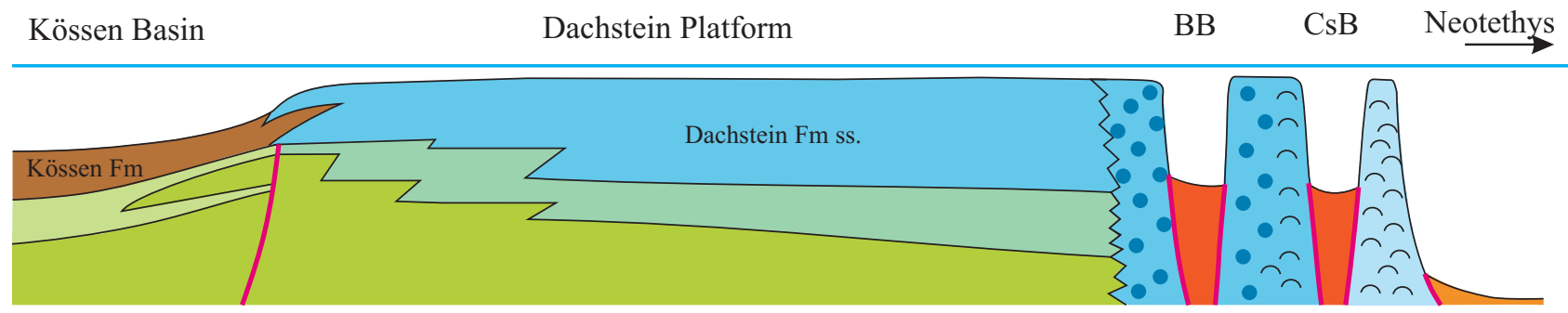

Rhaetian

\section{制赫}

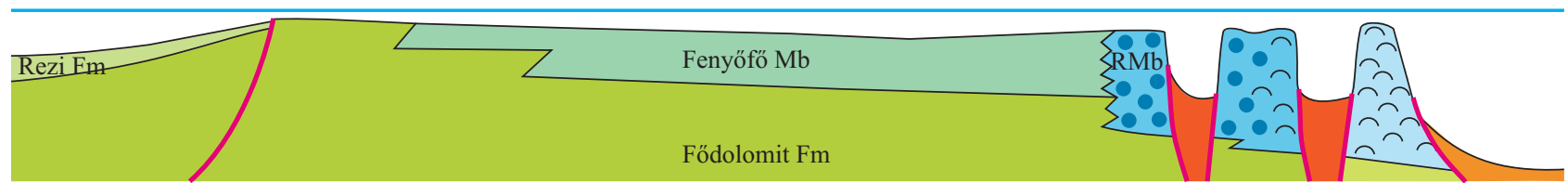

late Norian

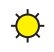

Gémhegy Fm

early Norian

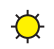

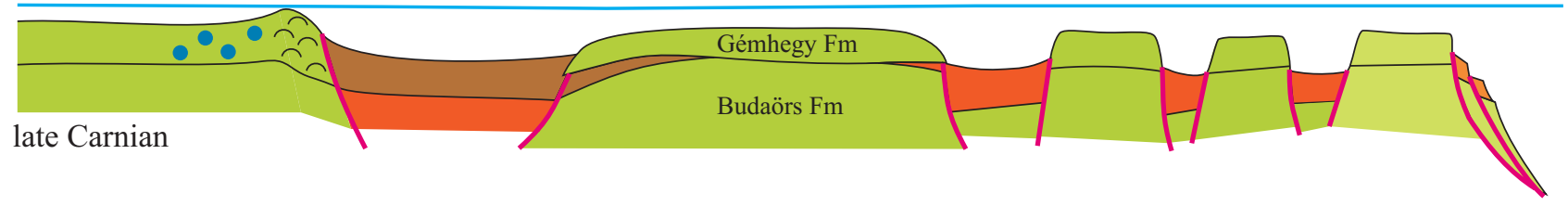

\begin{tabular}{|c|c|c|c|c|}
\hline $\begin{array}{l}\text { platform } \\
\text { dolomite }\end{array}$ & $\begin{array}{l}\text { platform } \\
\text { limestone }\end{array}$ & $\begin{array}{l}\text { platform } \\
\text { limestone/dolomite }\end{array}$ & $\begin{array}{l}\text { restricted basinal } \\
\text { dolomite }\end{array}$ & $\begin{array}{l}\text { basinal } \\
\text { marl }\end{array}$ \\
\hline $\begin{array}{l}\text { hemipelagic } \\
\text { limestone }\end{array}$ & oncoids & reef-builders & $\begin{array}{l}\text { semi-arid } \\
\text { climate }\end{array}$ & $\begin{array}{l}\text { humid } \\
\text { climate }\end{array}$ \\
\hline
\end{tabular}




\begin{tabular}{|c|c|c|c|c|c|c|c|c|c|c|c|c|}
\hline \multirow{2}{*}{ Formation } & \multirow[b]{2}{*}{ Location } & \multirow{2}{*}{$\begin{array}{l}\text { Litho- } \\
\text { facies }\end{array}$} & \multicolumn{2}{|c|}{ Fabric preservation } & \multicolumn{2}{|c|}{ Grade } & \multirow[b]{2}{*}{ Matrix } & \multirow[b]{2}{*}{ Grains } & \multicolumn{2}{|c|}{$\begin{array}{c}\text { Dolomite void- } \\
\text { filling }\end{array}$} & \multicolumn{2}{|c|}{ Calcite cement } \\
\hline & & & $\begin{array}{c}\text { Fabric } \\
\text { preserving }\end{array}$ & $\begin{array}{c}\text { Fabric } \\
\text { destructive }\end{array}$ & Partial & Pervasive & & & $\begin{array}{c}\text { VF-F- } \\
\text { M }\end{array}$ & M-C & BC & DD \\
\hline \multirow{2}{*}{ Gémhegy Dolomite } & \multirow{2}{*}{$\begin{array}{c}\text { Disznó Hill, } \\
\text { Vértes }\end{array}$} & Lf B & \multirow[t]{2}{*}{$\mathrm{x}$} & \multirow[b]{2}{*}{$\mathrm{x}$} & \multirow{2}{*}{\multicolumn{2}{|c|}{$\begin{array}{l}\mathrm{x} \\
\mathrm{x}\end{array}$}} & \multirow{2}{*}{$\begin{array}{c}\mathrm{cm} \\
\text { VF-F p-s }\end{array}$} & \multirow[b]{2}{*}{ bk-gh } & \multirow[t]{2}{*}{$\mathrm{x}$} & \multirow{2}{*}{$\begin{array}{l}\mathrm{x} \\
\mathrm{x}\end{array}$} & & \\
\hline & & Lf C & & & & & & & & & & \\
\hline $\begin{array}{c}\text { Gémhegy Dolomite - } \\
\text { Sédvölgy Dolomite } \\
\text { Mb }\end{array}$ & $\begin{array}{l}\text { Benedek Hill, } \\
\text { Bakony }\end{array}$ & Lf C & & $\mathrm{x}$ & & $\mathrm{x}$ & VF-F p-s & bk-gh & $\mathrm{x}$ & $\mathrm{x}$ & & \\
\hline \multirow{6}{*}{ Fődolomit } & \multirow[b]{2}{*}{$\begin{array}{l}\text { Aranyosvölgy, } \\
\text { Bakony }\end{array}$} & Lf B & \multirow{2}{*}{$\begin{array}{l}\mathrm{x} \\
\mathrm{x}\end{array}$} & \multirow[b]{2}{*}{$\mathrm{x}$} & \multirow{2}{*}{\multicolumn{2}{|c|}{$\begin{array}{l}\mathrm{x} \\
\mathrm{x}\end{array}$}} & \multirow[t]{2}{*}{$\mathrm{cm}$} & bk-gh & $\mathrm{x}$ & \multirow[t]{2}{*}{$\mathrm{x}$} & & \\
\hline & & Lf C & & & & & & $\begin{array}{l}\text { bk-gh, peloid, } \\
\text { intraclast }\end{array}$ & $\mathrm{x}$ & & & \\
\hline & \multirow{2}{*}{$\begin{array}{l}\text { Horogvölgy, } \\
\text { Vértes }\end{array}$} & Lf B & \multirow{2}{*}{$\begin{array}{l}\mathrm{x} \\
\mathrm{x} \\
\end{array}$} & & \multirow{2}{*}{\multicolumn{2}{|c|}{$\begin{array}{l}\mathrm{x} \\
\mathrm{x}\end{array}$}} & \multirow{2}{*}{$\begin{array}{c}\mathrm{cm} \\
\text { VF-F p-s }\end{array}$} & \multirow[b]{2}{*}{ bk-gh } & \multirow{2}{*}{$\begin{array}{l}\mathrm{x} \\
\mathrm{x}\end{array}$} & $\mathrm{x}$ & \multirow[b]{2}{*}{$\mathrm{x}$} & \\
\hline & & Lf C & & & & & & & & $\mathrm{x}$ & & \\
\hline & & Lf B & $\mathrm{x}$ & & & $\mathrm{x}$ & $\mathrm{cm}$ & & $\mathrm{x}$ & & $\mathrm{x}$ & \\
\hline & Vértes & Lf C & $\mathrm{x}$ & $\mathrm{x}$ & & $\mathrm{x}$ & VF-F p-s & $\begin{array}{l}\text { bk-gh, peloid, } \\
\text { intraclast }\end{array}$ & $\mathrm{x}$ & & & \\
\hline & Epöl, Gerecse & Lf B & $\mathrm{x}$ & & fs & $\mathrm{x}$ & $\mathrm{cm}$ & $\begin{array}{l}\text { bk-gh, peloid, } \\
\text { intraclast }\end{array}$ & $\mathrm{x}$ & & $\mathrm{x}$ & \\
\hline $\begin{array}{l}\text { Dachstein Limestone } \\
\text { Fm - Fenyőfö Mb }\end{array}$ & & Lf C & $\mathrm{x}$ & & fs & $\mathrm{x}$ & VF-F p-s & peloid, intraclast & & $\mathrm{x}$ & $\mathrm{x}$ & $\mathrm{x}$ \\
\hline & Ugod and & Lf B & $\mathrm{x}$ & & fs & & $\mathrm{cm}$ & & $\mathrm{x}$ & $\mathrm{x}$ & $\mathrm{x}$ & $\mathrm{x}$ \\
\hline & Porva, Bakony & Lf C & $\mathrm{x}$ & $\mathrm{x}$ & fs+nfs & $\mathrm{x}$ & & peloid, bioclast & & & & \\
\hline & & Lf B & $\mathrm{x}$ & & fs & & $\mathrm{cm}$ & & $\mathrm{x}$ & & $\mathrm{x}$ & \\
\hline $\begin{array}{l}\text { Fm s.s. } \\
\text { Fme }\end{array}$ & Porva, Bakony & Lf C & $\mathrm{x}$ & & fs & & & $\begin{array}{l}\text { bk-gh, peloid, } \\
\text { intraclast }\end{array}$ & & & & \\
\hline
\end{tabular}




\begin{tabular}{|c|c|c|c|c|c|c|c|c|}
\hline Sample & $\begin{array}{l}\text { Lithofacies } \\
\text { type }\end{array}$ & Matrix & Cement & $\begin{array}{c}\text { Fabric } \\
\text { preservation }\end{array}$ & Formation & Locality & $\delta^{18} \mathrm{O}$ & $\delta^{13} \mathrm{C}$ \\
\hline $27 \mathrm{a}$ & $\mathrm{C}$ & F-M & - & PFP & $\begin{array}{c}\text { GH, Sédvölgy } \\
\text { Dolomite Member }\end{array}$ & Veszprém & 0.6 & 3.2 \\
\hline $126 / 1$ & $\mathrm{C}$ & F-M & - & PFP & $\begin{array}{c}\text { GH, Sédvölgy } \\
\text { Dolomite Member }\end{array}$ & Veszprém & 0.5 & 3.1 \\
\hline $126 / 2$ & $\mathrm{C}$ & - & $\mathrm{C}$ & CEM & $\begin{array}{c}\text { GH, Sédvölgy } \\
\text { Dolomite Member }\end{array}$ & Veszprém & -0.7 & 2.4 \\
\hline 97 & $\mathrm{C}$ & F-M & - & FD & Gémhegy Dolomite & Vértes & 1.3 & 3.6 \\
\hline $98 / 2$ & B & $\mathrm{cm}$ & VF-F & GFP & Gémhegy Dolomite & Vértes & 1.9 & 3.2 \\
\hline $100 / 1$ & $\mathrm{C}$ & $\mathrm{cm}$ & VF-F & GFP & Gémhegy Dolomite & Vértes & 1.2 & 3.2 \\
\hline 99 & $\mathrm{C}$ ? & F-M & - & FD & Gémhegy Dolomite & Vértes & 1.5 & 3.8 \\
\hline $101 / 2$ & $\mathrm{C}$ & F-M & - & FD & Gémhegy Dolomite & Vértes & 1.2 & 2.9 \\
\hline $100 / 3$ & $\mathrm{C}$ & - & $\mathrm{C}$ & CEM & Gémhegy Dolomite & Vértes & -3.9 & 3 \\
\hline $101 / 1$ & $\mathrm{C}$ & - & $\mathrm{M}-\mathrm{C}$ & CEM & Gémhegy Dolomite & Vértes & -0.4 & 3.1 \\
\hline $27 b / 1$ & $\mathrm{C}$ & $\mathrm{cm}, \mathrm{VF}$ & - & PFD & Gémhegy Dolomite & Veszprém & 1.3 & 3.1 \\
\hline $27 b / 2$ & $\mathrm{C}$ & $\mathrm{cm}, \mathrm{VF}$ & - & FD & Gémhegy Dolomite & Veszprém & 0.8 & 3.2 \\
\hline 90 & B & $\mathrm{cm}$ & VF-F & GFP & Fődolomit & Vértes & 2.5 & 2.3 \\
\hline $91 \mathrm{a}$ & B & $\mathrm{cm}$ & VF-F & GFP & Fődolomit & Vértes & 1.7 & 2.5 \\
\hline $93 a$ & B & $\mathrm{cm}$ & VF-F & GFP & Fődolomit & Vértes & 2.5 & 2.5 \\
\hline 95 & B & $\mathrm{cm}$ & VF-F & GFP & Fődolomit & Vértes & 1.6 & 2.7 \\
\hline 96 & $\mathrm{C}$ & $\mathrm{cm}$ & VF-F & GFP & Fődolomit & Vértes & 3.1 & 2.6 \\
\hline 92 & $\mathrm{C}$ & $\mathrm{F}$ & - & MFP & Fődolomit & Vértes & 2.7 & 2.5 \\
\hline $102 / 2$ & $\mathrm{C}$ & $\mathrm{cm}, \mathrm{VF}$ & $\mathrm{F}$ & MFP & Fődolomit & Vértes & 2 & 1.7 \\
\hline $103 / 1$ & B & $\mathrm{cm}, \mathrm{VF}$ & VF-F & MFP & Fődolomit & Vértes & 2.5 & 2 \\
\hline $29 \mathrm{a} / 1$ & B-A & $\mathrm{cm}$ & VF-F & GFP & Födolomit & Veszprém & 1.3 & 3 \\
\hline 127 & B & $\mathrm{cm}$ & VF-F & GFP & Fődolomit & Veszprém & 1.1 & 3.1 \\
\hline $128 / 2$ & $\mathrm{C}$ & $\mathrm{cm}$ & VF-F & GFP & Fődolomit & Veszprém & 1.7 & 2.9 \\
\hline 28 & $\mathrm{C}$ & $\mathrm{cm}, \mathrm{VF}$ & - & PFP & Fődolomit & Veszprém & 2.1 & 3.2 \\
\hline 28 & $\mathrm{C}$ & $\mathrm{cm}, \mathrm{VF}$ & - & PFP & Fődolomit & Veszprém & 1.8 & 3.2 \\
\hline $28 / 1$ & $\mathrm{C}$ & $\mathrm{cm}, \mathrm{VF}$ & - & PFP & Fődolomit & Veszprém & 1.1 & 3 \\
\hline 28 & $\mathrm{C}$ & $\mathrm{cm}, \mathrm{VF}$ & - & PFP & Fődolomit & Veszprém & 2.4 & 3.2 \\
\hline $29 a / 2$ & B-A & - & $\mathrm{C}$ & CEM & Fődolomit & Veszprém & 0 & 3 \\
\hline $28 / 2$ & $\mathrm{C}$ & - & $\mathrm{M}-\mathrm{C}$ & CEM & Fődolomit & Veszprém & -0.8 & 2.9 \\
\hline $165 \mathrm{a}$ & B & $\mathrm{cm}$ & VF-F & GFP & DS, Fenyőfő Member & Gerecse & 1.2 & 3.6 \\
\hline $165 b$ & B & $\mathrm{cm}$ & VF-F & GFP & DS, Fenyőfő Member & Gerecse & 1 & 3.4 \\
\hline 167 & B & $\mathrm{cm}$ & VF-F & GFP & DS, Fenyőfő Member & Gerecse & -0.3 & 2.7 \\
\hline 164 & B & $\mathrm{cm}$ & VF-F & GFP & DS, Fenyőfő Member & Bakony & 1.2 & 2.5 \\
\hline $168 \mathrm{a} / 2$ & B-A & $\mathrm{cm}$ & VF-F & GFP & DS, Fenyőfő Member & Bakony & -0.3 & 2.4 \\
\hline $168 b$ & B & $\mathrm{cm}$ & VF-F & GFP & DS, Fenyőfő Member & Bakony & -1 & 1.2 \\
\hline $169 \mathrm{a} / 3$ & B & $\mathrm{cm}$ & VF-F & GFP & DS, Fenyőfő Member & Bakony & 0.3 & 3.2 \\
\hline $169 \mathrm{~b} / 2$ & B & $\mathrm{cm}, \mathrm{VF}$ & VF-F & GFP & DS, Fenyőfö Member & Bakony & 0.2 & 3 \\
\hline
\end{tabular}

